Article

\title{
Peatland Governance: The Problem of Depicting in Sustainability Governance, Regulatory Law, and Economic Instruments
}

\author{
Felix Ekardt ${ }^{1,2}$, Benedikt Jacobs ${ }^{3}$, Jessica Stubenrauch ${ }^{1,2, *(1)}$ and Beatrice Garske ${ }^{1,2}(\mathbb{C})$ \\ 1 Research Unit Sustainability and Climate Policy, 04229 Leipzig, Germany; felix.ekardt@uni-rostock.de (F.E.); \\ beatrice.garske@uni-rostock.de (B.G.) \\ 2 Faculty of Law, Faculty of Agriculture and Environment, and Interdisciplinary Faculty, Rostock University, \\ 18051 Rostock, Germany \\ $3 \quad$ BUND e.V., 10553 Berlin, Germany; benedikt.jacobs@bund.net \\ * Correspondence: jessica.stubenrauch@uni-rostock.de; Tel.: +49-341-492-77867
}

Received: 24 January 2020; Accepted: 12 March 2020; Published: 14 March 2020

check for updates

\begin{abstract}
Limiting global warming to well below 2 degrees Celsius and better even to 1.5 degrees Celsius, according to Article 2 paragraph 1 of the Paris Agreement requires global zero emissions in a very short time. These targets imply that not only emissions from degraded peatlands have to be avoided, but conservation and rewetting of peatlands are also necessary to figure as sinks to compensate for unavoidable residual emissions. However, with regard to instruments for meeting these targets, measuring, depicting, and baseline definition are difficult for greenhouse gas emissions from peatlands. In the absence of an easily comprehensible control variable (such as fossil fuels), economic instruments reach their limits. This is remarkable in so far as economic instruments can otherwise handle governance problems and react to various behavioral motivational factors very well. Still, peatlands can be subject to certain regulations and prohibitions under command-and-control law even without precise knowledge of the emissions from peatland use, which will be shown using the example of the European Union (EU) and German legislation. This paper is a contribution to governance research and illustrates that even comprehensive quantity-control instruments for fossil fuels and livestock farming - which would address various environmental problems and reflect findings from behavioral research regarding motivation towards sustainability—require complementary fine-tuning through command-and-control law, e.g., for integrating peatland governance.
\end{abstract}

Keywords: peatlands; peatland conservation; governance; sustainability; regulatory law; economic instruments; depicting; climate change; Paris Agreement; LULUCF

\section{Introduction: Research Issue of the Paper}

Although peatlands account for only about three percent of the land area, they are a significant carbon sink and store about 30 percent of terrestrially bound carbon (C) [1]. This corresponds to about two-thirds of carbon in the atmosphere and about four-fifths of the carbon of the earth's total terrestrial biomass [1-5]. Therefore, the protection of peatlands is directly linked to climate protection as one of the major challenges of the 21st century [6-9]. If peatlands are drained, for example, for agricultural use, carbon dioxide $\left(\mathrm{CO}_{2}\right)$ or nitrous oxide $\left(\mathrm{N}_{2} \mathrm{O}\right)$ are released into the atmosphere [10-12], and hot spots for greenhouse gas emissions (GHG emissions) are created [13]. In Europe, about 60 percent of peatlands have been drained in the past $[2,14,15]$. Similar developments are undertaken in other regions of the world. In Southeast Asia, large peatland areas are increasingly threatened by slash-and-burn and drainage, for example, for the cultivation of palm oil [2]. In Germany, peatlands are the largest 
single source of GHG emissions after the energy sector. They are responsible for around 37 percent of agricultural GHG emissions [16].

According to Art. 2 para. 1 of the Paris Agreement (PA) [17], global warming has to be limited to well below 2 degrees Celsius and better even 1.5 degrees Celsius compared to preindustrial levels. The legally binding character, especially of the climate target, can be seen in Art. 3 and 4 para. 1 PA. Based on the data of the Intergovernmental Panel on Climate Change (IPCC), this requires global decarbonization of all sectors in a very short time, probably in only one to two decades (or with a 50:50 probability in three decades; see in detail $[18,19])$. Thus, not only emissions from degraded peat soils have to be avoided, but major sinks have to be created in order to achieve zero emissions $([9,20]$ still related to the 2-degree-Celsius target; [21-23]). In addition to soils and forests, peat soils, in particular, could be such a sink to compensate for unavoidable residual emissions [23]. However, geoengineering approaches in this respect are comparatively expensive and risky [24].

Climate change can basically be traced back to the massive use of fossil fuels for electricity, heat, mobility, and plastics, but is also linked to the agricultural sector, for example, through energy-intensive mineral fertilizer production, animal food production, or the use of heavy machinery $[24,25]$. The intensification of agriculture with growing global land use-driven by feed or biomass production-increases the pressure on the use of environmentally sensitive areas such as peatlands. It endangers various ecosystem services and simultaneously contributing to biodiversity loss $[2,13,26,27]$. In this respect, the Convention on Biodiversity (CBD) [28] and its Aichi Targets, aims at halting the loss of biodiversity and ecosystems and reversing the trend i.e. improving the situation. In peatlands, certain endemic species of fauna and flora have adapted to the extreme living conditions. Among these are numerous endangered species [29]. Therefore, the drainage of the peatlands results in the loss of typical flora and fauna and leads to the extinction of sensitive species [30]. Furthermore, due to peatland drainage, progressive mineralization, and depletion of peat occur. Consequently, the peatland ecosystem cannot be preserved in the long term without countermeasures [31] and every land use that causes mineralization is not sustainable from the point of biodiversity conservation (for the sake of this contribution, sustainability means extending the idea of justice, i.e., the normative question of the right society, in spatio-temporal terms, i.e., towards intertemporal and global cross-border justice [24,32-34]). The lack of precipitation predicted in some regions due to global warming is an additional burden, especially for bogs [2,31].

It has been discussed elsewhere $[9,24,32,33]$ which policy instruments could reduce fossil fuel use to zero and significantly limit livestock farming - two central sustainability challenges. The latter would considerably decrease the pressure on the agricultural use of peatlands. The objective of this paper is to investigate which additional policy instruments-based on the binding international environmental targets set by the PA and the CBD-would be necessary to stimulate the rewetting of peatlands. In particular, a comparison of command-and-control options and economic policy options will be carried out. The governance analyses will be performed especially on the basis of an analysis of the major governance problem of peatlands: the problem of depicting certain governance units such as GHG emissions. The result will be to identify the most effective policy (or governance) approach in terms of peatlands.

\section{Methodology}

With regard to natural scientific data, the article methodically reviews the relevant literature regarding certain characteristics of peatlands and resulting GHG emissions in different phases of drained, used, and rewetted peatlands. On this basis, the effectiveness of previously used and potential alternative future policy instruments regarding peatland will be determined by applying a multi-method qualitative governance analysis (or steering analysis). A qualitative governance analysis assesses the effectiveness of existing and possible alternative governance instruments based on the given political targets and on the fact that various governance instruments can address typical governance problems, such as rebound effects, shifting effects, lack of target stringency, enforcement 
problems, and problems of depicting [9,24,32-34]. In this paper, the above-mentioned Art. 2 para. 1 of the Paris Agreement, supplemented by the CBD, serves as the target. In terms of governance problems, taking the example of peatlands with their specific characteristics, an important focus of this paper will be on the empirical identification of the problems of depicting. The problem of depicting describes the difficulty to precisely determine the amount of GHG emissions produced before and after the rewetting of different peatland sights, and thus, the problem to quantify exactly the amount of GHG emissions saved. Thus, this article aims to assess which policy instruments can respond adequately to the problem of depicting - under the auspices of the above-mentioned normative targets-using a multi-method qualitative governance analysis that builds on natural and behavioral scientific findings.

Governance analysis triangulates behavioral scientific findings from a wide variety of disciplinary and methodological backgrounds, and thus, gains insights into central governance problems with regard to sustainability. Knowledge of human behavior and especially of behavioral motivations is an indispensable basis for assessing the effectiveness of policy instruments, especially where instruments are developed that have not yet existed in reality (typical for sustainability issues)--or under other conditions [24]. Consequently, the methodology of qualitative governance research works by anticipating the behavior of the respective governance addressees on the basis of findings of their motivational state. This behavioral state has been deducted by means of a triangulation of surveys, experiments, participant observations, sociobiological derivations in other contributions, summing up findings from various disciplines such as sociology, economics, psychology, ethnology, cultural studies, human geography and others (on this as well as on the following [24,32-34]). Findings from these fields (which are not focused on special countries but on human motivation in general) can be condensed to a theory of the causes for unsustainability or the conditions of transformation, in which the actors' egoistic calculations, values, emotions, path dependencies, problems of collective goods, conceptions of normality and the interactions between actors play an important role. These behavioral motives are one reason why certain governance problems, such as rebound effects (including wealth effects), spatial/ sectoral/ shifting effects from one environmental problem to another, problems of depicting, lack of target stringency, and enforcement problems are to be expected in sustainability governance. On the other hand, it is not possible to observe the configuration of these governance problems precisely in reality, since it is a question of steering constellations that have not yet existed in this form (such as complete decarbonization within a few years). Nevertheless, further empirical insights on already existing instruments underline the findings on instruments that can be drawn from behavioral research, e.g., the fact that GHG emissions are macroeconomically shifted can be measured to some extent (albeit with severe difficulties) by determining the GHG emissions intensity of products on the basis of technical data and combining them with statistical import and export data [35].

Building on this behavioral science background, the above-mentioned normative targets and the identified characteristics of peatlands by means of a literature review, the present paper discusses in detail the otherwise neglected governance problem of depicting, which partly follows from the natural characteristics of peatlands-and, incidentally, also from land use and biodiversity itself-and draws instrumental conclusions from it. As we will see in the following, the major focus for effective sustainability governance has to be on the transnational level. This is why we will primarily mention this level in the course of this contribution. Since command-and-control regulation by now is typically situated on the nation-state level, we will nevertheless also mention some aspects of state legislation, for example, from Germany. However, since our analysis of governance problems is not specifically German or European, the results will also be relevant to other world regions.

\section{Natural Scientific Background: Peatland Ecosystems}

Peatlands are characterized by excess moisture due to high water saturation and the peat layer or the possible formation of peat [36]. Due to the high proportion of organic, non-mineralized substance, peatlands are categorized as organic soils. They can be divided into bogs and fens [37,38]. Peat is an organic, sedimentary deposit consisting mainly of the dead, humified plant material $[4,38]$. Due to 
the oxygen deficiency caused by the excess water, the material is not completely degraded and the structure is at least partially recognizable $[36,39,40]$. During peat formation, primary production exceeds the degradation of organic matter, which is severely slowed down due to anaerobic conditions and fewer soil animals [36]. It is estimated that 2 to 16 percent of primary production are accumulated in peat [39-41]. Hence, net primary production is not equivalent to peat accumulation and can, therefore, not be used as an indicator for the sequestration of $C$ in soil. Healthy peatlands grow a maximum of one millimeter per year in height [41]. In the past ten thousand years, peat bodies with a thickness of between five and ten meters have been formed in this way. In contrast to bogs, fens are supplied not only with rainwater but also with surface and groundwater. Therefore, compared to nutrient-poor and acidic bogs, they are more nutritious, have higher primary production, and are more biodiverse [36,41-43]. However, the division into bogs and fens cannot by far reflect a large number of different peatland ecosystems $[44,45]$. Depending on the availability of water, the nutrient content and $\mathrm{pH}$ value, the topology of the site and the development history of the peatland, many other ecological and hydrogenetic types of peatland can be distinguished [44].

The gas exchange of peatland ecosystems is just as complex and is furthermore frequently subject to anthropogenic influences. Healthy, i.e., growing and thus peat accumulating, peatlands have a positive long-term carbon balance [1,40]. However, exactly measured values diverge widely. Currently, it is estimated that 100 to 250 million $t$ of $C$ per year is bound by peatlands worldwide $[14,45,46]$. According to Swill [47], intact fens accumulate 200 to $300 \mathrm{~kg}$ of C per ha annually. This also corresponds with the mean sequestration rate of healthy peatland areas (both bogs and fens) in the northern hemisphere, according to Yu et al. [48]. However, sequestration rates of healthy peat soils between 20 and $1120 \mathrm{~kg} C$ per ha per year have been identified as well $[27,40,48]$. In very dry periods, the stored carbon in the form of $\mathrm{CO}_{2}$ can be re-emitted quickly [27,48]. Overall, the exact quantification of the $\mathrm{C}$ sequestration rate is difficult and can hardly be predicted (see chapter 3.1). Given the fact that the peat accumulation rate itself has a dispersion of 2 to 16 percent, the measured values of the $C$ sequestration rate of individual case studies show an even higher variance. Besides that, the location of the peatlands and the climatic factors, the distinction between absolute and specifically stored $\mathrm{C}$ (per area) and $\mathrm{C}$ storage rates, as well as the conversion between elemental $\mathrm{C}$ and $\mathrm{CO}_{2}$, are important factors to be taken into account when interpreting the results in the literature [40]. In addition to $\mathrm{CO}_{2}$, nitrous oxide $\left(\mathrm{N}_{2} \mathrm{O}\right)$ and methane $\left(\mathrm{CH}_{4}\right)$ are the two most important GHGs, which have to be considered under the aspect of climate relevance in the gas exchange of peatlands. In order to be able to compare the various impacts of the different GHGs better, usually, they are converted into $\mathrm{CO}_{2}$ equivalents $\left(\mathrm{CO}_{2} \mathrm{eq}\right)$ [12]. While healthy to semi-natural peatlands do not emit significant amounts of $\mathrm{N}_{2} \mathrm{O}$ or $\mathrm{CO}_{2}$ - they function as sinks $[27,40,49,50]$ - the $\mathrm{GHG} \mathrm{CH}_{4}$ is often emitted in considerable quantities. The climate balance of a peatland is calculated from the gross THG intake minus the gross THG emissions [51]. Therefore, depending on the circumstances, peatlands can be significant carbon sinks, but also contribute significantly to GHG emissions with their GHG fluxes [52]. Overall, there is an "extremely high temporal and spatial variability" [12] of GHG emissions in peatlands. The reasons for this can be found in the variety of peatland ecosystems, the heterogeneity within a peatland site, the vegetation range from open or dammed peat to high forest, the different types of GHG emissions, their different climate relevance and opposing reactions to changed climatic conditions such as varying water levels [49]. In order to assess the climate impact of semi-natural peatlands, it is necessary to compile a balance of the various GHGs. Thereby, the time horizon is of major importance, as the global warming potential of $\mathrm{CH}_{4}$ decreases over time. $\mathrm{CH}_{4}$ emissions in peatlands occur as a result of the anaerobic decomposition of plant biomass by specialized microorganisms and the formation of methanogenic archaea (methane bacteria) [53-55]. $\mathrm{CH}_{4}$ is emitted via three main paths-Diffusion, bubble formation, and transport via plant tissue, especially of shunt plants, which possess aerenchyma, and thus, allowing direct exchange between peat soils and the atmosphere [53]. According to Couwenberg et al. [49], $\mathrm{CH}_{4}$ emissions from peat soils with shunt plants rise, on average, to $170 \mathrm{~kg}$ of $\mathrm{CH}_{4}$ per ha per year. In contrast, peat soils without shunt plants emit, on average, only $50 \mathrm{~kg} \mathrm{CH}_{4}$ 
per ha and year $[40,53]$. However, if long time horizons are considered, natural and semi-natural peatlands have a proven cooling effect on the climate $[27,40,56]$ and also in the short term (over several decades), $\mathrm{CH}_{4}$ emissions are roughly offset by $\mathrm{C}$ storage in bogs [57]. The Intergovernmental Panel on Climate Change (IPCC), therefore, estimates the mitigation potential through restoration and reduced conversion of peatlands at 0.3 to $3 \mathrm{GtCO}_{2} \mathrm{eq} / \mathrm{yr}$, which is a medium effect among instruments proposed by the IPCC. Thus, regardless of their immediate mitigation potential, peatlands play a large role in long-term climate preservation, as--unlike vegetation-they are able to store GHG emissions for centuries [58] (p. 18,24). The conservation of wetlands and peatlands is very effective to store C, while their impact on other factors such as water resources and food security may vary regionally [58]. Hence, in order to be able to use the potential sink functions of peatlands, intact peat ecosystems that are not managed or are managed in a semi-natural, and therefore, sustainable manner are required [9] to avoid contrary effects [59]. The traditional drainage of peatlands for agricultural land use in order to lower the (ground) water level [41] results in the airtight peat body coming to the surface and oxygen $\left(\mathrm{O}_{2}\right)$ penetrating into the pores of it. This leads to (rapid) mineralization of the carbon and nitrogen stocks in peat $[36,43,49]$. Summer water levels of 60 to $90 \mathrm{~cm}$ below the surface lead to maximum peat mineralization [27] and the highest $\mathrm{CO}_{2}$ and $\mathrm{N}_{2} \mathrm{O}$ emissions. Mineralization causes for these emissions to rise sharply under oxic conditions, while $\mathrm{CH}_{4}$ emissions decline and are even negligible from a water level of $20 \mathrm{~cm}$ below the surface $[49,53,60]$. However, the drainage trenches can still emit large quantities of $\left.\mathrm{CH}_{4}[27,49]\right)$. For $\mathrm{CO}_{2}$, a non-linear correlation between the drainage depth and the increasing emission rate has been observed [12,40,49,55].

The National Inventory Report in Germany [61] calculates that the peatlands emit 45.7 million $t$ of $\mathrm{CO}_{2}$ equivalents per year, having estimated the size of the peatlands up to $18,239 \mathrm{~km}^{2}$. This accounts for 5.1 percent of total GHG emissions in Germany. Drained peatlands are thus the largest single source of GHG emissions outside the energy sector in Germany [13,62]. The vast majority (75 percent) derives from agricultural land [63]. According to IPCC [64], $\mathrm{CO}_{2}$ emissions from drained peatlands range from -2 to $31 \mathrm{t}$ per hectare (ha) per year, for $\mathrm{N}_{2} \mathrm{O}$ from 2 to $38 \mathrm{~kg} \mathrm{~N}_{2} \mathrm{O}$ per ha per year. In Central Europe, according to Höper [63], $\mathrm{CO}_{2}$ emissions from farmland average $11.2 \mathrm{t}$ of $\mathrm{CO}_{2}$ per ha per year for arable land and $4.6 \mathrm{t}$ of $\mathrm{CO}_{2}$ per ha per year for grassland. Other studies [65-68] demonstrate the wide range of $\mathrm{N}_{2} \mathrm{O}$ emissions from 0 to $61 \mathrm{~kg} \mathrm{~N} \mathrm{~N}_{2} \mathrm{O}$ per ha per year for arable land and from 1.15 to $41 \mathrm{~kg}$ $\mathrm{N}_{2} \mathrm{O}$ per ha for grassland. If the water level is constantly high (above $20 \mathrm{~cm}$ below the surface), $\mathrm{N}_{2} \mathrm{O}$ emissions are negligibly low [66]. $\mathrm{CH}_{4}$ emissions, on the other hand, rise significantly at a constantly high-water-level and range from -0.2 to $763 \mathrm{~kg} \mathrm{CH}_{4}$ per ha $[40,53]$. The ratio of emissions from drained peat soils to total emissions (excluding land-use) determined using the Greenhouse gas Emission Site Type approach (GEST approach, see chapter 3.2) was 37 percent in Mecklenburg-Western Pomerania, 36 percent in Schleswig-Holstein and nine percent in Brandenburg [69]. The average GHG emissions from peatlands in Germany [65] are shown in Table 1.

During the rewetting of drained peatlands, the mineralization rate decreases with increasing water level; $\mathrm{CO}_{2}$ and $\mathrm{N}_{2} \mathrm{O}$ emissions decrease simultaneously. Ideally, peat growth resumes [59]. Specific case studies prove that the reduction in $\mathrm{CO}_{2}$ and $\mathrm{N}_{2} \mathrm{O}$ emissions can take place within a few months [49]. At water levels near the surface, $\mathrm{CO}_{2}$ emissions are negligibly low, even a net $\mathrm{CO}_{2}$ uptake occurs. In addition, the typical vegetation of those biotopes returns to bogs after only a few years $[2,65]$. However, the question of whether new (significant) carbon sinks can actually be created by rewetting is still controversially discussed in science $[2,65,70]$. This is due to the increasing $\mathrm{CH}_{4}$ emissions, which either remain below the level of semi-natural peatlands or can even rise above this. Drösler et al. [13] inundated peatlands and shunt plants with aerenchyma can regularly be associated with high $\mathrm{CH}_{4}$ emissions $[49,65,71]$. Furthermore, a temporary $\mathrm{CH}_{4}$ peak can cause anaerobic decomposition of easily decomposable plant material [72]. Therefore, some scientists [13] conclude that a clear climate protection effect can only be achieved if the water level is aligned in accordance with the natural state of the area. 
Table 1. Greenhouse gas (GHG) balances by type of land use and peat type (average values (range [sample size])), own illustration, according to Drösler et al. [65].

\begin{tabular}{|c|c|c|c|}
\hline $\begin{array}{l}\text { Type of Peatland Use } \\
\text { and/or Peat Type }\end{array}$ & $\begin{array}{c}\text { Fens } \\
{\left[\mathrm{C} \mathrm{CO}_{2} \text { eq ha }^{-1} \mathrm{a}^{-1}\right]}\end{array}$ & $\begin{array}{c}\text { Bogs } \\
{\left[\mathrm{t} \mathrm{CO}_{2} \text { eq ha } \mathbf{a}^{-1} \mathrm{a}^{-1}\right]}\end{array}$ & $\begin{array}{l}\text { Water Level } \\
{[\mathrm{cm}]}\end{array}$ \\
\hline arable land & $\begin{array}{c}33.8 \\
(14.2 \text { to } 50.0[4])\end{array}$ & no data & $\begin{array}{c}-70 \\
(-29 \text { to }-102)\end{array}$ \\
\hline grassland (intensive, middle) & $\begin{array}{c}30.9 \\
\text { (21.3 to } 40.7[5])\end{array}$ & $28.3[1]$ & $\begin{array}{c}-49 \\
(-39 \text { to }-98)\end{array}$ \\
\hline grassland (extensive, dry) & $\begin{array}{c}22.5 \\
\text { (19.5 to } 30.9[4])\end{array}$ & $20.1[1]$ & $\begin{array}{c}-29 \\
(-14 \text { to }-39\end{array}$ \\
\hline grassland (extensive, wet) & $\begin{array}{c}10.3 \\
\text { (5.8 to } 16.3[4])\end{array}$ & $\begin{array}{c}2.2 \\
(0 \text { to } 4.4[2])\end{array}$ & $\begin{array}{c}-11 \\
(6 \text { to }-25)\end{array}$ \\
\hline bogs (dry) & & $\begin{array}{c}9.6 \\
\text { (5.3 to } 12.1[3])\end{array}$ & $\begin{array}{c}-18 \\
(-9 \text { to }-25)\end{array}$ \\
\hline semi-natural (renatured) & $\begin{array}{c}3.3 \\
(-4.3 \text { to } 11.9[5])\end{array}$ & $\begin{array}{c}0.1 \\
(-1.8 \text { to } 2.9[3])\end{array}$ & $\begin{array}{c}-10 \\
(-7 \text { to }-14)\end{array}$ \\
\hline inundation & $\begin{array}{c}28.3 \\
\text { (10.6 to } 70.7[4])\end{array}$ & $\begin{array}{c}8.3 \\
\text { (6.1 to } 10.4 \text { [2]) }\end{array}$ & $\begin{array}{c}14 \\
(-8 \text { to } 36)\end{array}$ \\
\hline
\end{tabular}

The average GHG saving potential of renatured or extensive peatlands is regularly set at 30 to $35 \mathrm{t}$ $\mathrm{CO}_{2}$ equivalents per ha and year [2,66,71]. In this context, the highest GHG reduction potential lies in heavily drained and intensively farmed areas. In Schleswig-Holstein, between 0.8 and 1.3 million $t$ of $\mathrm{CO}_{2}$ equivalents could be saved per year: 0.8 million $\mathrm{t}$ if all peat soils intensively used as grassland and arable land were rewetted and converted to extensive grassland and 1.3 million $t$ if semi-natural cultivation of paludicultures were established [27,69]. In addition to climate protection, synergies with soil and biodiversity protection could be achieved as well $[5,27]$. However, in already extensively used peatlands, a contrary effect may occur as they might be populated by protected species, which would disappear in case of rewetting [31]. In particular, if amongst them are plant species listed on the Red List, a legal environmental constraint exists. Thus, intensively used peatlands should be renaturalized, despite the strong use of competition [29]. Those peatlands provide a significantly higher GHG reduction potential and (if at all) only a low conflict potential with nature conservation. Directly related to the latter is the need for frugality in relation to the consumption of animal derived-products and the corresponding reduction of land use for feed production, which has widely been discussed before and can also be justified from a human rights perspective $[24,34,73]$. In addition, rewetting measures generally have a positive effect on the water quality of the receiving waters and can contribute to flood protection, prevent erosion and retain nutrients and pollutants, thus also contributing to the achievement of the EU Water Framework Directive and the Nitrates Directive. In individual cases, however, rewetting can also lead to the mobilization and increased release of phosphate $[5,27,74]$. As a response to this, the Top Soil Removal (TSR) process, which removes the upper layer of the strongly mineralized and, therefore, very nutrient-rich peat (maximum $30 \mathrm{~cm}$ ), was established. However, renaturation costs increase significantly due to the TSR process [74].

\section{Results: Problem of Depicting-Lack of Clarity in the Data}

\subsection{Measurability of Greenhouse Gas Reductions}

In order to be able to offset emission reductions, e.g., within the framework of international climate agreements, and thus promoting the renaturation through a quantity or price control instrument, reduction potentials have to be quantified reliably. On the one hand, this requires identifying the actual state of the emissions as a baseline and, on the other hand, estimating future emissions for the duration of the project (50 to 100 years). Technically GHG fluxes of ecosystems can be measured by applying chamber measurements or eddy covariance towers [75]. However, the interannual variations and the high spatial heterogeneity would require high-resolution perennial measurements. Given the cost of 10,000 Euro per ha per year [27], this approach is only feasible for pilot and research projects. In addition, problems remain regarding the measurability of the GHG fluxes of certain types 
of peatland and the exact consideration of different site characteristics. For peatland covered by forests or whose vegetation consists mainly of heathland and bushland, a reliable measurement method does not yet exist because the $\mathrm{CO}_{2}$ release of the soil can (partly) be neutralized by the $\mathrm{CO}_{2}$ sink of the trees and peat growth can be restricted [52,76]. Another difficulty is to determine the amount of $C$ absorbed by the peatland from the ratio of absorbed $C$ and released $C$ (Net Ecosystem Change, NEE). Besides that, there is a knowledge gap concerning the emission behavior after the rewetting of stowed surfaces without vegetation cover [50]. Therefore, the available high-value data on GHG fluxes from peatlands are far from covering the whole spectrum of potential site characteristics [49]. In fact, there is hardly any data on agriculturally used rain bogs. $\mathrm{CO}_{2}$ data on wet fens do not exist, and annual measurement periods of $\mathrm{CO}_{2}$ flows from stowed areas are still missing. In addition, GHG balances of peatlands show a very high variance. In the past, this has led to individual measurements of the climate relevance of each peatland conserving initiative [12]. Therefore, the question of the current state of research on the depictability of emissions is even more important. In this context, it appears necessary to estimate the emission balances before the start of rewetting and during the rewetting initiative using suitable indicators.

\subsection{Depictability of Greenhouse Gas Emissions}

With regard to climate protection, the level of emissions arising or avoided from land use is, in principle, much more difficult to determine than emissions from the use of fossil fuels. Within land use, there is a large number of small individual emitters, and individual emission items are often difficult to verify and quantify and heavily depend on the circumstances of the individual case. Thus, reliable monitoring has proven to be difficult [9]. The accurate quantification of emissions as a prerequisite for the implementation of certificate trading requires measurements before, during, and after a rewetting project. The necessary technology via the chamber method (small scale up to one square meter) or the eddy covariance (large scale up to one $\mathrm{km}^{2}$ ) is available and tested, however, due to the high cost and time expenditure it is primarily feasible for research and pilot projects, as already mentioned [50]. Regarding the individual GHG emissions, the potential depictability can, therefore, be presented as follows:

- $\mathrm{CO}_{2}$ emissions are the major factor in the GHG balances of drained (!) peatlands [77], and they do not differentiate between bogs and fens. Thus, measurement data from one specific peatland site can also be used to verify other peatlands [50]. Furthermore, there is a clear correlation between water and emission level: emissions decrease rapidly after rewetting and are negligibly low from water levels near the surface (see chapter 2). Whether a $\mathrm{CO}_{2}$ absorption takes place after rewetting also depends on the development of vegetation, which binds $C$ via photosynthesis. However, the most challenging parameter to identify is the level of emissions before rewetting (baseline) in order to be able to determine the possible (potential) GHG savings. This is because the baseline can vary from peatland to peatland and even at one site on a small scale. First, the results suggest that the dynamic $C$ stocks and the subordinate gyttjas have a strong influence on the GHG fluxes and the $\mathrm{C}$ balance of the individual peatlands. However, research focusing on the latter aspects is still widely missing (see, e.g., [78,79]).

- Compared to $\mathrm{CO}_{2}$ and $\mathrm{N}_{2} \mathrm{O}$ emissions, significantly more scientific data regarding $\mathrm{CH}_{4}$ emissions from peatlands is available. At higher water levels, emissions rise sharply in line with the water level [80-82]. As already mentioned, the presence of "fresh" biomass alongside shunt plants is a major factor for the generation of $\mathrm{CH}_{4}$ after rewetting [55]. One exception which is worth mentioning is black alder, which impacts $\mathrm{CH}_{4}$ emissions in two ways: On the one hand, the aerenchyma tissue allows for the direct exchange between the anaerobic zone and the surface. On the other hand, black alder provides for the active transport of $\mathrm{O}_{2}$ into the rhizosphere where aerobic conditions are created, leading to an oxidation of $\mathrm{CH}_{4}$ [77]. However, the fact that $\mathrm{CH}_{4}$ emissions are negligibly low at water levels below $20 \mathrm{~cm}$ [49] can at least facilitate the estimation of the baseline, which is consequently relatively simple to determine. The estimation of the emission 
behavior after rewetting, though, is problematic. Here the values measured so far diverge widely, as the emission development is influenced by many different factors on a small scale.

- $\quad \mathrm{N}_{2} \mathrm{O}$ emissions from rewetted peatlands are negligibly low to non-existent [50]. The emission values of drained sites, meanwhile, show a major divergence. Peatlands with an average water level of fewer than $20 \mathrm{~cm}$ below the surface cause a large dispersion of $\mathrm{N}_{2} \mathrm{O}$ emissions, which means the reduction potential can hardly be determined and even less predicted in general terms [50]. However, $\mathrm{N}_{2} \mathrm{O}$ emissions always decrease after a successful rewetting. A disregard of this decrease in the depiction of the GHG emissions reduction potential, therefore, leads to incorrect results since $\mathrm{N}_{2} \mathrm{O}$ emissions can reach considerable values [49]. Particularly high emissions were measured with highly fluctuating groundwater levels [27]. This underlines once again that rewetting with the intention of reducing emissions requires good groundwater management. In contrast, a clear link between fertilization and $\mathrm{N}_{2} \mathrm{O}$ emissions is not always apparent. However, $\mathrm{N}_{2} \mathrm{O}$ emissions are largely dependent on the level of nitrate concentration in the soil water, which can be increased by non-site-adapted fertilization, respectively, overfertilization [83]. So far, there are no appropriate proxies to reliably depict the $\mathrm{N}_{2} \mathrm{O}$ flows. Rather, neglecting the $\mathrm{N}_{2} \mathrm{O}$ emissions in the baseline assessments determines their conservativeness.

Potential models estimating GHG emissions from peatlands or GHG reductions from rewetting them require simple indicators as input parameters in order to be manageable (simple to monitor), verifiable, and reproducible. Three input parameters are currently discussed in literature; the water level, the subsidence rate, and the type of vegetation [50]. Additionally, the factor of peat thickness is of major importance-especially in shallow peatlands [49]. Meta-analyses of large-scale data sets have shown that the mean annual water level is the most appropriate single parameter for estimating annual GHG emissions and should always be set close to zero, although the correlation of GHG emissions with water levels may vary from site to site [84]. The water level can be determined inexpensively and reliably using automatic water level loggers [50]. However, large-scale (at least nationwide, if not Europe-wide) rewetting projects aligned with the targets of the Paris Agreement would require such a high-resolution monitoring network that this option appears unrealistic in practice, especially since even small reductions in water levels can lead to a substantial increase in peat mineralization and thus $\mathrm{CO}_{2}$ emission fluxes [77]. Measuring water levels using remote sensing methods would simplify monitoring but is not (yet) available. Still, Bechtold et al. [85] have shown that data obtained via remote sensing technologies (more precisely the reflection coefficients of the $\mathrm{C}$ band) correlate with the fluctuation of the groundwater level. This could be an important step towards monitoring on a national or international scale. In addition, there is an approach to simulate water levels using hydrological models [27]. However, initial research results from peatlands in Germany reveal major uncertainties. Tiemeyer et al. [86] have developed a statistical model based on land use, peatland cover in the surrounding of the level, altitude relative to the surrounding area, land use cover in surrounding area, climatic water balance in summer and location type of the organic soils. Thus, to regionalize the mean long-term groundwater field distance and to produce maps with the expected value of the mean long-term mire water level is possible. However, a validation showed that only about 45 percent of the variance of the water levels could be explained by this method.

Subsidence is defined as the shrinkage or loss of height of the peat body due to oxidation. According to Couwenberg et al. [50], the water level correlates with the subsidence rate for specific regions. The lowering of drained peat layers is related to the water level in a linear way but varies largely in different parts of the world. An approach for determining GHG emissions by lowering the peat soil is currently being developed in Australia [50]. This method is particularly promising in the tropics, where the loss in the height of the peat layer can be as much as several centimeters per year. $\mathrm{CO}_{2}$ emission rates can be estimated based on the assumption of a certain oxidation fraction in the subsidence. An additional advantage is the potential to use remote sensing technologies for monitoring $[11,53]$. However, the estimation of GHG emissions after rewetting still poses problems as 
a swelling of the peat body can occur [27]. Furthermore, no statements about $\mathrm{N}_{2} \mathrm{O}$ and $\mathrm{CH}_{4}$ emissions can be derived from this approach.

Vegetation is a reliable indicator of water levels, but is at the same time affected by numerous other parameters that are relevant for GHG emissions, such as nutrient availability, $\mathrm{pH}$, land use and land use history. In addition, vegetation is, directly and indirectly, responsible for some of the emissions. Vegetation regulates the GHG exchange via the organic substance supplied for the formation of $\mathrm{CO}_{2}$ and $\mathrm{CH}_{4}$, reduces soil moisture, and provides bypasses for $\mathrm{CH}_{4}$ emissions via aerenchymas. Vegetation also provides information on water levels on a longer time scale and can, therefore, be used to reflect GHG flows over the year but also enables small-scale mapping [50]. However, models that use vegetation as an indicator need to be calibrated for different climatic and phytogeographic regions. In addition, vegetation responds only slowly to changes in environmental conditions, i.e., it may take several years before a change in the water level becomes apparent in the vegetation. While the extinction of certain species tends to proceed quite rapidly, it takes a long time for new species to be established [50]. Apart from that, as the water level decreases, the direct correlation with the vegetation becomes increasingly vague. In addition to the vegetation parameter, water level observations are, therefore, mandatory [50]. Besides that, there is a lack of scientific publications on GHG emissions from peat soils that adequately describe the predominant vegetation. However, vegetation as a proxy allows monitoring by remote sensing or mapping to record the baseline [27]. On this basis, Couwenberg et al. [50] have developed the Greenhouse Gas Emission Site Types (GEST) approach. The study provides a practical tool to quantify GHG emissions from degraded and rewetted bogs in Central Europe [50]. Based on the vegetation form concept of Koska et al. [87], which integrates floristic and ecological parameters as a classification method, certain areas can be assigned to a specific vegetation form. Thereby, the presence or absence of specific groups of species is decisive. These forms of vegetation are characterized by average water levels, nutrient availability, and $\mathrm{pH}$ value and are assigned to so-called water levels. Couwenberg et al. [50] have supplemented these vegetation forms with specific GHG emissions. Missing values were generated by extrapolation, a regression model, and by including expert knowledge, a matrix was created. Based on this matrix, large peat areas can be divided into different emission site types, and $\mathrm{CO}_{2}$ and $\mathrm{CH}_{4}$ emissions derived. In order to be able to make an ex-ante estimation of the emission reduction through rewetting, the development of vegetation is modeled on the basis of literature data and expert opinions and then compared with the baseline. $\mathrm{N}_{2} \mathrm{O}$ emissions are not taken into account due to a lack of proxies and to ensure the conservativity of the approach [49]. However, the method is criticized for lacking the capacity to distinguish between extensively and intensively used grassland. Also, individual crop species on arable land cannot be identified [69], and lastly, GHG fluxes are ultimately still only estimated on the basis of literature data, extrapolation, and expert knowledge. Besides this, particularly in the range from -15 to $+5 \mathrm{~cm}$, the classification of water levels is very coarse, although this is decisive for $\mathrm{CH}_{4}$ emissions [27,88]. Therefore, Tiemeyer et al. [84] question whether bioindicators such as vegetation are in fact able to provide reliable data across different peatlands since individual measured values cannot easily be transferred to other sites. A systematic, supra-regional evaluation that assesses the vegetation classes in their accuracy to predict GHG fluxes derived from water levels does not yet exist. In addition, the method is generally conservative, as emissions from deep-drain sites are likely to be higher, and $\mathrm{CH}_{4}$ and $\mathrm{N}_{2} \mathrm{O}$ emissions from drainage ditches have not been taken into account. Nonetheless and despite all criticism, the estimation of the climate relevance of peat soils carried out according to the GEST method is the currently best estimation available.

Overall, not only the variety of different peatland ecosystems and the wide range of influencing factors impede the exact mapping of actual GHG fluxes. Rather, the influencing factors themselves (temperature, precipitation, $\mathrm{CO}_{2}$ concentration in the atmosphere, etc.) change continuously and partly contrary due to the high interannual variability, which complicates the prognosis [40]. Furthermore, and increasingly, the impact of global climate change aggravates the management of rewetting projects and their reproducibility. For example, Huth et al. [77] observed that a one-month flood period 
stemming from one heavy rainfall event accounted for 70 percent of the total $\mathrm{CH}_{4}$ emissions measured throughout the whole two-year project. Reliable methods for estimating GHG emissions both in the drained (baseline) and in the rewetted state would, therefore, also have to include extreme weather events. However, this seems hardly achievable due to their complex predictability. Moreover, measurement studies over a period of more than five years hardly exist [40].

\subsection{Baseline Problem}

Since the decisive factor for rewetted peatlands is the GHG reduction potential rather than the sink function, the calculations have to take into account the peat depletion time- the time it would take for the peat layer to be completely degraded, and no additional emissions occur. Ideally, the depletion time is larger than in the project scenario [7]. The peat thickness factor, therefore, plays an important role and needs to be further reviewed in case of implementation in carbon markets [49]. This is especially applicable for shallow peatlands where emissions are more dependent on peat thickness than on water level [50]. The question arises whether it is possible to renature areas with low peat thickness in such a way that they become a sink respectively a "healthy" peatland ecosystem again in the long term, or whether they should be drained further so that no additional GHGs are emitted in the absence of a peat layer. If the latter is the case, it should be possible to make quantifiable and generally valid statements about the (minimum) peat thickness above which rewetting is no longer useful. This, however, requires a case-by-case assessment, which also depends on the availability of water and the conditions of the surrounding areas. If, for example, the peatlands are located in an elevated position at the edge of large peatland areas, the water level cannot be raised accordingly. On the other hand, a rewetting project can also have an effect on the surrounding areas, especially in fens, and cause increased $\mathrm{CH}_{4}$ emissions, since a water level increase cannot be limited to the fens only. However, if the increased $\mathrm{CH}_{4}$ emissions after rewetting are below the total possible savings at a time horizon of 100 years, the option of rewetting should be chosen. This offers the advantage that mineralization comes to a halt after anaerobic conditions have developed, and new peat can be formed.

There are current research approaches that determine peat thickness using ground-penetrating radar (GPR). However, this approach has so far been limited to natural and near-natural sites and, therefore, cannot yet be used for renaturation measures [77,89]. Other research projects attempt to determine the distribution of wetlands and peatlands in the tropics and their peat thickness using a combination of hydrological models, remote sensing methods to determine soil moisture and geomorphology from topographic data [90]. Gumbricht et al. [90] come to the conclusion that the peat volume (and thus the C storage) of peatlands in the tropics is more than twice as high as previously assumed. This underlines the uncertainty in estimating the baseline. As discussed previously, legally regulating the reduction potential does not only require identifying the baseline (the actual state of the emissions) but also the future emissions for the duration of the project (50-100 years). However, corresponding maps are only partly available in Europe, and even for Germany no complete, parcel-specific mapping of the soil types exists [91]. In general, the quality of peatland mapping varies significantly both internationally and within peatland rich countries such as Russia, Indonesia, or Finland [11,53]. In many cases, the existing mapping is outdated and insufficient [92]. This is particularly true with regard to the topicality of the form of land use. And while in the tropic's new peat-rich and largely untouched peatlands are still being discovered and have to be protected [93], in Central Europe, it is above all a matter of renaturing already damaged peatlands.

\section{Results: Policy Instruments of Peatland Governance}

In terms of climate and biodiversity protection targets mentioned above, the aim of the law must be to conserve existing peatlands and peat bodies respectively to rewet former peatlands or to manage them sustainably. As mentioned earlier, the ongoing loss of stored $C$ in former peatlands that are not rewetted would be much higher than the (still quite hard to capture) unclear emissions from rewetting peatlands. Hence, in the end, peatlands have to be used in a way that storing $\mathrm{C}$ can take 
place or not used at all to fully utilize the storage capacity. Sustainable use for peatlands that have previously been intensively used for agriculture would be acceptable if they were used as extensive grassland or for the cultivation of paludicultures [94,95]. In the following section, various governance approaches, focusing on the European Union (and selected national examples, including remarks on the limits of national solutions), will be reviewed regarding their potential effectiveness in meeting the climate and biodiversity targets through peatland conservation. Thereafter, the governance approaches such as economic, command-and-control, and voluntary approaches will be discussed in comparative terms. The focus on transnational, namely European, solutions is due to the fact that national solutions typically cannot prevent shifting effects as a crucial governance problem $[24,32-34,96]$.

\subsection{Empirical Status Quo of Agricultural and Environmental Law Regarding Peatland Conservation-Limited Focussing and Failure of Existing Command-and-Control Options and Subsidy Schemes}

At the international level, in addition to the already mentioned the PA and the CBD, the Ramsar Convention (Convention on Wetlands of International Importance especially as Waterfowl Habitat, [97]) is particularly concerned with the conservation and sustainable use of wetlands. However, the identification of peatlands and the extent to which this includes former peatlands that are already in use depends to a large extent on the individual national states and their monitoring. For example, in Germany, around 870,000 ha are designated as Ramsar wetlands [98]. However, there is only one peatland area among them, so that no significant steering effect for peatland conservation is achieved (Federal Agency for Nature Conservation Germany 2018 [99]).

Apart from that, many natural to semi-natural peatland areas (a total of 95,600 ha) in the EU are classified as Natura 2000 areas in accordance with Annex 1 No. 7 of the European Habitats Directive $[100,101]$. Pursuant to Art. 2 para. 1 of the Habitats Directive, the designation of protected areas is intended to contribute to preserving species diversity and natural habitats as well as wild fauna and flora. A favorable conservation status should be maintained or restored (Art. 2 para. 2 Habitats Directive). According to Art. 6 para. 2 of the Habitats Directive, a general prohibition of degradation applies to habitats. As previously discussed, if rewetting is undertaken for reasons of climate protection, conflicts with nature conservation may simultaneously arise. However, the agricultural use of peatlands is not fundamentally restricted in protected areas. Appropriate prohibitions and directives only need to ensure that the requirements of Art. 6 para. 1 Habitats Directive are fulfilled. Special management requirements for farmers can, therefore, be imposed, but intensive management of the peatlands-additionally associated with the use of mineral fertilizers and pesticides-is not excluded in the Natura 2000 areas either $[102,103]$. There is no effective protection of peatlands or any incentive to rewet or extensively manage them. Since the delimitation of the protected areas is regularly based on the remaining peatland vegetation, the peat body, which extends considerably further, often lies outside the areas of the Habitats Directive [31,100].

Examples from the national level raise questions, too. In Germany, for example, the general requirements of the Federal Nature Conservation Act (BNatSchG [104]) have to be analyzed in addition to the regulations of soil and water protection law. The BNatSchG pursues the overriding objective of protecting nature, the landscape and biological diversity as well as the performance, functional and regenerative ability of the ecosystem in the long term ( $\S 1$ para. 1 no. $1,2 \mathrm{BNatSchG).} \S 1$ para. 3 no. 2 BNatSchG stipulates that soils must be preserved in such a way that they can "fulfill their function in the ecosystem". According to $\S 15$ BNatSchG, interventions in nature must, therefore, be avoided, and, in the case of unavoidable interventions, compensatory or replacement measures must be undertaken. According to $\S 14$ para. $1 \mathrm{BNatSchG}$, interventions in nature also include changes in the groundwater level, so that the drainage of peatlands must generally be regarded as a relevant intervention (intervention regulation). At the same time, however, according to $\S 14$ para. 2 sentence $1 \mathrm{BNatSchG}$ agricultural and forestry use does not constitute an intervention in nature insofar as the objectives of nature and landscape conservation are taken into account. This is generally fulfilled if the rules of good practice, as defined in the BNatSchG itself and in the Federal Soil Conservation 
Act (BBodSchG [105], see below) are complied with (§ 14 para. 2 sentence 2 BNatSchG). The rules of good practice are listed as examples in $\S 5$ para. 2 BNatSchG. $\S 5$ para. 2 no. 5 BNatSchG determines that farmers should refrain from tilling grassland on peatland sites. However, it is not precisely defined when peatland is present and, in particular, which groundwater level marks the threshold for the existence of a peatland. Moreover, the rules of good practice are merely guidelines for action and no legally enforceable prohibitions (BVerwG, the judgment of 01.09.2016 4 C 4.15, para. 17). Therefore, the BNatSchG cannot prevent the plowing up of grassland on peatland areas. In addition, the avoidance and compensation requirements in the event of a grassland tilling are probably rarely applied in official practice [106]. Furthermore, in the BNatSchG, extensive grassland use of peatlands is equated with intensive use. Therefore, the protection of existing peatlands or sustainable management is not guaranteed. Rather, the BNatSchG provides for an unjustified exemption from nature protection law and privilege of agricultural land use without differentiating between individual site conditions and types of use $[107,108]$.

The EU Water Framework Directive does not address the subject. The German Water Resources Act (WHG [109]) fundamentally prohibits the conversion of grassland into arable land on buffer strips of watercourses and in floodplains, including peatlands ( $\$ 38$ para. 4 no. $1 \mathrm{WHG}, \S 78$ a no. $7 \mathrm{WHG}$ ). The damming, lowering, and diverting of groundwater is subject to approval pursuant to $\S 8$ para. 1 in conjunction with $\S 9$ para. 2 no. 1 WHG. However, no separate permission is required for soil drainage for agricultural, forestry or horticultural use pursuant to $\S 46$ para. 1 no. 2 WHG. The agricultural use of peatlands is, thus privileged, and the targeted drainage of peatlands is not prevented under the WHG.

The potential contribution of soil protection to reducing GHG emissions has not yet been incorporated into soil protection law either, and specific requirements for the protection of peatlands have not been laid down. At the EU level, not even a Soil Framework Directive has been established. Similarly, on a national level, the German BBodSchG lacks appropriate regulations as well [96]. The principles of good professional practice in accordance with $\S 17$ BBodSchG, which include humus conservation, are also formulated in abstract terms so that no binding requirements can be derived [110]. In addition, the BBodSchG is subsidiary to the special provisions of the fertilizer law (lex specialis) pursuant to $\S 3$ No. 4 BBodSchG and does not empower any authority to impose orders in case of agricultural land use. Consequently, legally binding measures to protect peatlands used for agricultural purposes cannot be enacted. This is pernicious, as also the special provisions of fertilizer law do not yet sufficiently aim at site-specific management or fertilization and the preservation or building-up of organic soil matter $[34,111]$. Thus, e.g., German command-and-control legislation, in particular, the BBodSchG and fertilizer law do not require the maintenance of the sink function of the peatlands and a prohibition of intensive use of them as grassland or arable land yet, thus counteracting the stringent climate protection goals The poor integration of the sink capacity of mires and their potential regarding climate protection into national legislation has, e.g., been revealed regarding the Finnish peatland policy [112].

This does not imply per se that it is not possible to establish a more effective command-and-control regime. It is important to say that since the discussed norms here serve only as an example. But generally speaking, command-and-control approaches in sustainability governance show serious flaws in dealing with the above-mentioned typical governance problems $[24,32-34,96]$. This is due to the fact that command-and-control regulation addresses single actions, plants, or sites and therefore faces difficulties in dealing with problems of quantities-e.g. climate protection is not about optimizing a single action or plant, but about overall GHG emission reductions. Command-and-control can regulate climate protection for single actions and plants, but cannot avoid that rebound effects and shifting effects occur-and enforcement is very often difficult due to the fact that numerous actions, plants, etc., would have to be monitored, especially with regard to agriculture (ibid.).

These findings raise the question to what extent the Common Agricultural Policy of the European Union (CAP), as a central instrument for promoting the management of the agricultural sector by means 
of subsidies, stimulates the sustainable use of peatlands. Within the framework of direct payments per ha under the first pillar of the CAP, the drainage-based management of peatlands has so far been specifically subsidized which made a previously economically unattractive activity economically viable [113]. The direct payments are linked to the fulfillment of the cross-compliance [114] and can be increased by the greening premium [115]. The cross-compliance regulations contain standards for the preservation of agricultural land "in good agricultural and environmental condition" (GAEC), which according to GAEC standard 6 also include the preservation of soil organic matter. However, these are merely basic requirements for farming without differentiating sites, so that no specific implications for peatland use can be derived from GAEC 6. Within the scope of greening, Art. 45 para. 1 Regulation (EU) No. 1307/2013 [115] envisages the "designation of environmentally sensitive permanent grassland", which may then no longer be converted into arable land or plowed. This has to include at least the peatlands and wetlands of the Natura 2000 areas [116]. However, even peatlands that are identified as environmentally sensitive permanent grasslands may continue to be managed intensively-and, thus, not sustainable. In addition, the ban on the conversion or plowing of environmentally sensitive permanent grassland did not apply until 1 January 2014, so that up to 31 December 2013 converted grassland could continue to be used for agricultural purposes without endangering the maintenance of the greening premium. On the other hand, the cultivation of paludicultures (such as reeds, bulrushes, or rushes) is excluded from support under the first pillar of the CAP $[95,101]$. The CAP's direct payments have thus so far run contrary to and even hinder the objectives of sustainable peatland use and the associated climate protection.

The aim of project funding under the second pillar of the Common Agricultural Policy (CAP) is to achieve sustainable management of natural resources and climate protection (Art. $4 \mathrm{~b}$ European Agricultural Fund for Rural Development (EAFRD) Regulation [117]). The European Agricultural Fund for Rural Development (EAFRD), which co-finances the projects of the second pillar, is, alongside the European Regional Development Fund (ERDF), the European Social Fund (ESF), the European Maritime and Fisheries Fund (EMFF) and the Program for Environment and Climate Action (LIFE), the most important funding source for the implementation of the Habitats Directive. It thus also serves to protect peatlands [118]. According to Art. 5 para. 1 no. 5 EAFRD Regulation, one funding priority, is to support a climate-resistant and low-carbon economy. This also includes the promotion of $C$ storage in agriculture and forestry. As part of investment measures, compensation payments can be made to farmers, associations, or private forest owners for the purchase of land or the rewetting of peatlands in accordance with Art. 17 EAFRD Regulation $[118,119]$. In addition, farmers can receive a five-year subsidy for voluntarily enhancing environmental services exceeding the basic requirements within the framework of the agri-environment-climate measures (AECM) pursuant to Art. 28 EAFRD Regulation. This includes action-oriented AECM, such as extensification measures of permanent grassland and result-oriented AECM for the conservation of plant genetic valuable grassland vegetation or protected biotopes [119]. In addition, peatland restoration measures under the thematic objective four "reduction of $\mathrm{CO}_{2}$ emissions" are eligible for ERDF funding [120,121]. In contrast to the first pillar of the CAP; however, the second pillar is significantly underfunded and, due to the voluntary nature of the support measures, already has a lower steering effect $[16,34,113,120]$.

However, regarding respective payments for ecosystem services (PES) and voluntary approaches in general, preliminary research has shown that the achievable environmental services largely depend on the concrete project design, the available project funds, involved stakeholders, e.g., their rhetorical skills, and the duration of the project [122,123]. Also, there is always a risk that the protective measures that lead to payable environmental services are reversed after the funding expires [34] (pp. 385-387] [124]. Furthermore, besides the limited availability of money, the voluntary nature of funding such as CAP and PES shows a general flaw if taking the motivational insights from Section 2 of this contribution into account: Given the problematic human motivation in terms of sustainability, it is simply not very likely that voluntary measures can serve as a major element of the (based on PA and $\mathrm{CBD}$ ) required great transition [24]. For instance, the worldwide promotion of biomass cultivation is 
a serious threat to the preservation of peatlands that cannot be overcome sufficiently by voluntary protection measures. In various EU states, fostering biomass production has increasingly led to the conversion of grassland-including peatland areas-to arable land which cannot be completely prevented by reducing subsidies for biomass. This is also true for the requirements for land conversions for the production of liquid biomass (Art. 17 para. 3, 4 Renewable Energy Directive [125], Art. 7 b para. 3 and 4 Biofuel Directive [126]. The so-called "sustainability criteria" do not exactly define when peatland is worth protecting ([106], with more details in [33]).

Similarly, in the tropics, biofuel next to feedstuff is produced frequently at the expense of forests with intact peatlands, whereby national (in particular voluntary) regulations have so far been largely ineffective [127-129]. Furthermore, a regulatory gap regarding biofuel production has been identified at the international level [130]. Accordingly, it can be concluded that, although voluntary instruments may show a certain positive influence on the protection of single peatland areas, they are most probably not appropriate to meet the scope of the challenges of the targets from PA and CBD, especially against considering the high pressure on land use [131].

\subsection{Empirical Status Quo of Climate Economic Instruments for Peatland Conservation}

It is questionable whether existing economic instruments, including the European Union Emissions Trading Scheme (EU ETS), will change the present position of the sink function of peatlands within the framework of climate policy. Until the world climate summit in Durban in 2011, peatland protection was not separately represented in the climate negotiations. Only $\mathrm{N}_{2} \mathrm{O}$ emissions were covered $[7,8]$. In the second commitment period of the Kyoto Protocol (KP) [132] (2013 to 2020), sinks are included in Art. 3 para. $3 \mathrm{KP}$ and-subject to certain restrictions-are also recognized as eligible under Art. 3 para. 4 [9]. The section "Wetland Drainage and Rewetting" (WDR) was included as a new activity aiming to better take into account GHG emissions from drained peatland sites and the associated reduction potential [133] (p. 316). In the PA, potential sinks, such as peatlands are covered by Art. 4 para. 1 PA. In accordance with Art. 5 para. 1 PA, Member States are required to take appropriate measures to maintain and increase the sink function. However, in this respect, no specific monitoring, control, or enforcement mechanisms exist.

In the EU, the climate and energy package aims to reduce GHG emissions by 20 percent by 2020 and by 40 percent by 2030 compared to the emissions of 1990 [134]. By 2050, GHG emissions are to be reduced by 80 to 95 percent, and GHG neutrality is to be achieved [135]. The EU target is divided into a European target for EU emissions trading and national targets for sectors not covered by the EU ETS. While the EU ETS sector covers GHG emissions from the production of mineral fertilizers and the transport associated with land use in relation to the agricultural and forestry sector (Land Use, Land-Use Change, and Forestry, LULUCF), other GHG emissions from land use are exempted [9]. Regarding the emissions not covered by the EU ETS, the EU Burden Sharing Regulation 2018/842 [136] requires Member States to implement nationally binding targets aiming to reduce emissions by a total of 30 percent compared to the emission of 2005 [134]. Further regulation is based on the EU LULUCF Regulation 2018/841 [137]. Whereas from 2021 to 2025 wetlands only need to be optionally reported by a Member State and included in the reduction obligation pursuant to Art. 4 of the LULUCF Regulation, this becomes mandatory from 2026 (Art. 2 para. $1 \mathrm{~b}$ in conjunction with Art. 2 para. 2 of the LULUCF Regulation). However, the EU has so far been rather hesitant about including the LULUCF sector into emissions trading instruments [8,9]. Until 2030, for example, LULUCF credits will only have limited eligibility for emission reduction targets in other sectors [98]. Nevertheless, there is hope that in the future, it will be easier to define and confine these areas and that the measurability, reportability, and verifiability (MRV) of emissions will be less difficult than other even smaller land-use emissions [9].

Besides that, on the free carbon market, a few certification standards have begun to include emission reduction through rewetting projects as a category [138,139]. On the voluntary carbon market, both private individuals and organizations or companies can purchase certificates on a voluntary basis to offset their GHG emissions [137-140]. The voluntary carbon market exists aside from the mandatory 
carbon market and is a pure trade approach without a cap. It is much smaller than, for instance, the EU ETS. The non-existent reporting obligations of the so-called Voluntary Emission Reductions (VER) have led to little information on the exact nature of this market $[27,141]$. Due to the lack of regulation, a vast amount of different quality standards have been developed, which are hard to keep track of [129]. Such standards have the purpose of ensuring the integrity of the projects and guaranteeing that the projects are actually implemented and achieve real GHG savings (Verified Carbon Standard, VCS 42 million t; Climate Action Reserve, 9 million t; Gold Standard, 8.5 million t; see [27]). Most of these standards are built on the requirements of the Kyoto Protocol's project-based Clean Development Mechanism (CDM) [140] and do not recognize rewetting projects. Only the Verifies Carbon Standard (VCS), the International Standard Organization (ISO), Social Carbon and Climate, Community, and the Biodiversity Standards (CCB) include a project category of rewetting. For example, in the LULUCF and AFOLU sector (Agriculture, Forestry, and Other Land Use) of the VCS, the project category Wetlands Restoration and Conservation (WRC) has existed since March 2001 facilitating rewetting projects [138,140]. So far, however, the efforts have been far from achieving the objective of Art. 2 para. 1 PA.

\section{Discussion and Concluding Remarks: Possible Governance Problems and Possible Policy Options to Overcome Them}

After all, it remains difficult to monitor the areas, especially those which can be rewetted. This applies in particular to the peripheral areas of degraded peatlands, where the question of peat thickness must be taken into account. While GHG flows depend on numerous, small-scale, and temporally variable parameters, they can still be mapped quite well by methods such as the GEST approach. Nevertheless, additional data is required for each individual rewetting project. This refers in particular to the already mentioned factors, including peat thickness, water availability, and nutrient content (respectively danger of eutrophication). However, peat soils themselves also differ considerably in terms of their pedogenesis and geogenesis, and these differences, in turn, have a considerable influence on possible sustainable use, renaturation, the $\mathrm{C}$ balance, water storage and conductivity, GHG release and much more [78]. In addition, the gyttjas, which lie below to many peat soils, are still poorly researched.

The remaining wide range of potential emission reductions and the problem of measuring them precisely, entail that ambitious cap-and-trade approaches on supranational or even international level are not suitable as a primary instrument for peatland conservation (measured especially against the above-mentioned climate target). This is remarkable in so far as these cap-and-trade instruments, if they are linked to easily comprehensible control variables or governance units such as fossil fuels or livestock products, can otherwise handle governance problems very well and react to various behavioral, motivational factors (more detailed in [25,32]). If, however, a problem of depicting arises and cannot be dealt with by switching to an easily comprehensible control variable, economic instruments reach their limits. Knowledge about the exact distribution of peatlands, their condition (drainage depth, peat thickness, type of land-use), and their potential for rewetting (both technically and with regard to the risk of eutrophication and conflicts with other nature conservation objectives) seems still too fragmentary. Further issues arise with the baseline problem. This stands in contrast to another governance sector-biodiversity governance. There, biodiversity itself is also confronted with the problem of depicting. However, this can be addressed by switching to the drivers of the widespread biodiversity loss, namely fossil fuels, and livestock products [25,33,142]. For focusing on a specific ecosystem such as peatlands, however, the approach to tackle the identified drivers is an indispensable first step, but would not be sufficiently precise to protect or to rewet peatland areas accordingly [25,33,142].

Referring to the EU and, e.g., to Germany, there is a manageable amount of peatland areas which is therefore well ascertainable so that a command-and-control regulation-unlike for the entirety of agriculture-seems relatively feasible. For example, in Germany, peatland areas cover only about 4 percent of the land area and 7.3 percent of the agricultural area [16]. Even if the quality of the 
mapping (especially for the peripheral areas of the peatlands) is quite heterogeneous, the peat-rich centers of peatlands are well known. Target-oriented, precise applicability of a command-and-control approach also results from the knowledge that rewetting with a water level at the height of the top edge of the terrain generally leads to the highest GHG reductions. Accordingly, a rewetting requirement for all peat soils that can be rewetted technically and under climate and nature conservation considerations geared to the groundwater level appears to be the most practicable option. The aim of this command-and-control option should be to ensure, at least at the national, but even better at the EU level, long-term legal protection of nature-like water levels at all peatland sites. Command-and-control measures are also required to prevent draining of further peatland areas. Measures such as a prohibition of the plowing up of grassland, a strict ban on the use of peatlands as arable land, and a ban on the cultivation of fast-growing plantations on peatland areas would be appropriate in this respect. At EU level - as it is necessary to avoid shifting effects—either the new extended conditionality under the CAP (which will replace cross-compliance and greening in the future, see below) or the Habitats Directive would be a possible starting point for such a requirement. Furthermore, the approach would have to be supported by additional instruments prohibiting peat cutting and peat import throughout the EU. In this respect, it is important to note that groundwater elevations cannot be implemented on a small scale and be precisely limited to individual peatland areas. Thus, groundwater elevations always influence the groundwater level (and therefore possibly also the potential for cultivation) of the surrounding areas. Consequently, the definition of the exact boundaries of rewetting projects will be a permanent challenge with regard to governance problems, even in a command-and-control approach. Effective implementation, therefore, requires a more precise definition of peatlands than has hitherto been the case.

The command-and-control approach should be complemented by changes in subsidy law at the EU level. This is because, under aspects of climate protection, the highest GHG savings can be achieved on deep-drained and intensively farmed sites. Thereby, high-yield locations (e.g., vegetable cultivation in floodplains) are the exception. Also, intensively used areas are usually marginal yield locations and are often only cultivated due to the availability of subsidies. Thus, if the damaging peatland subsidies were abolished, these locations could no longer be used economically. Consequently, the existing subsidies under the CAP should be eliminated. However, the forthcoming CAP reform does not adequately address this issue. In fact, the existing structure of the CAP will most probably be maintained in the future [117]. And even if the new enhanced conditionality includes adequate protection of wetlands and peatlands in the GAEC standards in addition to the maintenance of permanent grassland and the preservation of soil organic matter, specified requirements that go beyond the existing rules are not envisaged. Instead, more overall sovereignty in distributing all agricultural subsidies will be given to the Member States [118]. Improved peatland protection would, therefore, still be conceivable but seems unlikely due to a lack of obligation. The explicit support for intensive peatland use tends to remain in place for the post-2020 CAP funding. Accordingly, the recommendation to reduce the existing counterproductive subsidies under the first pillar of the CAP, while at the same time supporting peatland renaturation measures or a more appropriate agricultural use by means of further EU funds, remains valid.

These strategies would have to be supplemented by the above-mentioned overarching instruments, which reduce the intensification pressure in agriculture firstly in Europe but due to highly globalized feed and food markets also globally. Elsewhere, it has been shown that a cap-and-trade approach for fossil fuels with a cap of zero in about two decades and a cap-and-trade approach for livestock husbandry or an obligation to link livestock farming to the agricultural area on the farm area would be, combined with an increase in area-related taxes, the most effective instruments to reduce the land-use pressure (more precisely $[9,24,32,143,144]$ ). The fact that such approaches have to be combined with border adjustments in order to prevent shifting effects outside the EU has also been discussed elsewhere. In the end, such a stringent policy with regard to fossil fuels and regarding minimized livestock densities in Europe would ultimately strengthen the possibility of increased 
peatland protection not only in Europe but also on a global level. At the same time, the steering load, which lies on the command-and-control law—which has been proven indispensable for effective peatland protection-would then be considerably lower.

Thus, the following conclusions, as well as policy implications, can be drawn from the foregone discussion (and they do not depend on a specific national background due to its overarching basis in insights on motivational and governance problems); Even if quantity governance approaches such as cap-and-trade schemes can typically address and prevent governance problems such as shifting effects, rebound effects and enforcement deficits very well, they are unable to optimally solve every problem. This is even true for a relatively homogeneous good such as GHGs. In principle, economic instruments can often avoid the problem of depicting by referring to an easily comprehensible control variable such as livestock products or fossil fuels. However, if they are unable to do, so they will face similar, sometimes even larger problems than command-and-control law. Besides peatland protection, this problem is also known from the discussion on the direct pricing of biodiversity $[24,33,131]$. At the same time, command-and-control law can fulfill a very important supplementary function with distinct rules or prohibitions, as it is the case regarding the protection and rewetting of peatlands-especially if the respective command-and-control law is implemented without too many complicated details and is used in addition to overarching economic instruments (e.g. addressing fossil fuels and livestock products and probably also bioenergy production (on the latter see [33]) aiming to reduce intensification pressure in agriculture.

As regards study limitations of the present contribution, it should not be neglected that rewetting peatlands can lead to conflicts with other nature conservation objectives that have to be reflected sufficiently within the regulation [145] that we did not deal with in detail here. In particular, the risk of eutrophication of downstream waters due to the rewetting of former agriculturally used peatlands with increased nutrient contents must be taken into account to ensure sustainability in terms of both climate and biodiversity protection. Beyond the EU, it should also be noted that the institutional conditions for both regulatory law and economic instruments are often not very favorable in developing countries. However, precisely the relatively simple governance approaches developed here could principally make sense in those countries, too.

Author Contributions: F.E. was responsible for conceptualization, aspects of governance analysis, governance options, and supervision; B.J. contributed the review of natural scientific findings and insights to governance issues; J.S. und B.G. contributed further governance-related contents and were responsible for the translation. All authors have read and agreed to the published version of the manuscript.

Funding: This research was partly funded by the German Federal Ministry of Education and Research (BMBF) within the BonaRes project InnoSoilPhos (No. 031B0509).

Acknowledgments: The authors gratefully acknowledge the German Federal Ministry of Education and Research (BMBF) for funding the BonaRes project InnoSoilPhos (No. 031B0509). We also thank our colleague Katharine Heyl for proofreading.

Conflicts of Interest: The authors declare no conflict of interest.

\section{References}

1. Joosten, H.; Sirin, A.; Couwenberg, J.; Laine, J.; Smith, P. The role of peatlands in climate regulation. In Peatland Restoration and Ecosystem Services; Ecological Reviews; Bonn, A., Allott, T., Evans, M., Joosten, H., Stoneman, R., Eds.; Cambridge University Press: Cambridge, UK, 2016; pp. 63-76.

2. Niedermair, M.; Plattner, G.; Egger, G.; Essl, F.; Kohler, B.; Zika, M. Moore Im Klimawandel: Studie Des WWF Österreich; Umweltbundesamt GmbH: Vienna, Austria, 2011.

3. Schägner, J.P. Kosteneffektiver Klimaschutz durch Moorschutz-Moorrenaturierung als Klimaschutzmaßnahme. Ökologische Wirtsch. 2009, 1, 28-29.

4. Trepel, M. Zur Bedeutung von Mooren in der Klimadebatte: Jahresbericht des Landesamtes für Natur und Umwelt Des Landes Schleswig-Holstein; Landesamtes für Natur und Umwelt des Landes Schleswig-Holstein: Flintbek, Germany, 2008. 
5. Zak, D.; Augustin, J.; Trepel, M.; Gelbrecht, J. Strategien und Konfliktvermeidung bei der Restaurierung von Niedermooren unter Gewässer-, Klima- und Naturschutzaspekten, dargestellt am Beispiel des nordostdeutschen Tieflandes. Telma 2011, 4, 133-150.

6. IPCC. Climate Change 2014: Mitigation of Climate Change: Working Group III Contribution to the Fifth Assessment Report of the Intergovernmental Panel on Climate Change; Cambridge University Press: Cambridge, UK, 2014; pp. 873-875.

7. Wolters, S.; Tänzler, D.; Theiler, L.; Drösler, M. Entwicklung von Konzepten für einen Nationalen Klimaschutzfonds zur Renaturierung von Mooren; Umweltbundesamt: Dessau-Roßlau, Germany, 2013.

8. Couwenberg, J.; Joosten, H.; von Unger, M.; Emmer, I. Peatlands, Forests and the Climate Architecture: Setting Incentives through Markets and Enhanced Accounting; Umweltbundesamt: Dessau-Roßlau, Germany, 2016.

9. Ekardt, F.; Wieding, J.; Garske, B.; Stubenrauch, J. Agriculture-related climate policies-Law and governance issues on European and global level. Carbon Clim. Law Rev. 2018, 4, 316. [CrossRef]

10. Höper, H. Wasserregulierende Maßnahmen auf landwirtschaftlich genutzten Mooren. Presented at the Moore im Kontext der Ramsar-Konvention - Schutz und nachhaltige Nutzung, Bonn, Germany, 23 May 2018.

11. Joosten, H. The Paris agreement and the role of Peatlands. Presented at the Future of the Voluntary Carbon Markets in the Light of the Paris Agreement: Perspectives for Soil Carbon Projects, Bonn, Germany, 3 May 2018.

12. Augustin, J. Emission, Aufnahme und Klimarelevanz von Spurengasen. In Landschaftsökologische Moorkunde; Succow, M., Joosten, H., Eds.; Schweizerbart Science Publishers: Stuttgart, Germany, 2001; pp. 28-36.

13. Drösler, M.; Freibauer, A.; Adelmann, W.; Augustin, J.; Bergmann, L.; Beyer, C.; Chojnicki, B.; Förster, C.; Giebels, M.; Görlitz, S.; et al. Klimaschutz durch Moorschutz in der Praxis: Ergebnisse aus dem BMBF-Verbundprojekt Klimaschutz-Moornutzungsstrategien 2006-2010; Von Thünen-Institut: Braunschweig, Germany, 2011.

14. Joosten, H. Moorschutz in Europa: Restauration und Klimarelevanz. In Moor in der Regionalentwicklung; Wagenfeld; Ströhlen; BUND Landesverband Niedersachsen, Ed.; BUND Niedersachsen: Hannover, Germany, 2006; pp. 35-42.

15. Joosten, H.; Couwenberg, J. Bilanzen zum Moorverlust: Das Beispiel Europa. In Landschaftsökologische Moorkunde; Succow, M., Joosten, H., Eds.; Schweizerbart Science Publishers: Stuttgart, Germany, 2001; pp. 406-408.

16. Wichtmann, W. Aktuelle Forschungs- und Umsetzungsprojekte in Deutschland: Paludikulturen. Presented at the Moore im Kontext der Ramsar-Konvention - Schutz und nachhaltige Nutzung, Bonn, Germany, 23 May 2018.

17. United Nations. Adoption of the Paris Agreement (PA); United Nations: New York, NY, USA, 2015.

18. Ekardt, F.; Wieding, J.; Zorn, A. Paris agreement, precautionary principle and human rights: Zero emissions in two decades? Sustainability 2018, 10, 2812. [CrossRef]

19. Rockström, J.; Gaffney, O.; Rogelj, J.; Meinshausen, M.; Nakicenovic, N.; Schellnhuber, H.J. A roadmap for rapid decarbonization. Science 2017, 1269-1271. [CrossRef]

20. Höhne, N.; Kuramochi, T.; Sterl, S.; Röschel, L. Was bedeutet das Pariser Abkommen für den Klimaschutz in Deutschland? Kurzstudie Von NewClimate Institute im Auftrag von Greenpeace; NewClimate-Institute for Climate Policy and Global Sustainability gGmbH: Berlin, Germany, 2016.

21. van Vuuren, D.P.; Deetman, S.; van Vliet, J.; van den Berg, M.; van Ruijven, B.J.; Koelbl, B. The role of negative $\mathrm{CO}_{2}$ emissions for reaching $2{ }^{\circ} \mathrm{C}$-Insights from integrated assessment modelling. Clim. Chang. 2013, 118, 15-27. [CrossRef]

22. Gasser, T.; Guivarch, C.; Tachiiri, K.; Jones, C.D.; Ciais, P. Negative emissions physically needed to keep global warming below $2{ }^{\circ} \mathrm{C}$. Nat. Commun. 2015, 6, 7958. [CrossRef] [PubMed]

23. Smith, P.; Davis, S.J.; Creutzig, F.; Fuss, S.; Minx, J.; Gabrielle, B.; Kato, E.; Jackson, R.B.; Cowie, A.; Kriegler, E.; et al. Biophysical and economic limits to negative $\mathrm{CO}_{2}$ emissions. Nat. Clim. Chang. 2016, 6, 42-50. [CrossRef]

24. Ekardt, F. Sustainability. Transformation, Governance, Ethics, Law; Springer: Berlin, Germany, 2019.

25. IPCC. Climate Change 2014: Synthesis Report: Contribution of Working Groups I, II and III to the Fifth Assessment Report of the Intergovernmental Panel on Climate Change; Core Writing Team, Pachauri, R.K., Meyer, L.A., Eds.; IPCC, Intergovernmental Panel on Climate Change: Geneva, Switzerland, 2015.

26. Millennium Ecosystem Assessment. Ecosystems and Human Well-Being: Synthesis. A Report of the Millennium Ecosystem Assessment; Island Press: Washington, DC, USA, 2005.

27. Paul, S.; Alewell, C. Moorregeneration als Klimaschutzmaßnahme: Eine Recherche zur neuen Kyoto-Aktivität; Bundesamt für Umwelt: Basel, Switzerland, 2013. 
28. United Nations. Convention on Biological Diversity (CBD); United Nations: New York, NY, USA, 1992.

29. Succow, M. Ökologische (phytozoenologische) Moortypen. In Landschaftsökologische Moorkunde; Succow, M., Joosten, H., Eds.; Schweizerbart Science Publishers: Stuttgart, Germany, 2001; pp. 229-234.

30. Landgraf, L. Bedeutung der Moore für den Landschafts- und Stoffhaushalt. Telma 2000, 30, 146-148.

31. Ssymank, A.; Ullrich, K.; Vischer-Leopold, M.; Belting, S.; Bernotat, D. Handlungsleitfaden, Moorschutz und Natura 2000“ Für die Durchführung von Moorrevitalisierungsprojekten; Bundesamt für Naturschutz: Bonn, Germany, 2015.

32. Garske, B. Ordnungsrechtliche und ökonomische Instrumente der Phosphor-Governance und ihre Bezüge zu Böden, Gewässern, Biodiversität und Klima; Metropolis-Verlag: Marburg, Germany, 2020.

33. Hennig, B. Nachhaltige Landnutzung und Bioenergie. Ambivalenzen, Governance, Rechtsfragen; Metropolis-Verlag: Marburg, Germany, 2016.

34. Stubenrauch, J. Phosphor-Governance in ländervergleichender Perspektive-Deutschland, Costa Rica, Nicaragua: Ein Beitrag zur Nachhaltigkeits- und Bodenschutzpolitik; Metropolis-Verlag: Marburg, Germany, 2019.

35. Peters, G.P.; Minx, J.C.; Weber, C.L.; Edenhofer, O. Growth in emission transfers via international trade from 1990 to 2008. Proc. Natl. Acad. Sci. USA 2011, 108, 8903-8908. [CrossRef]

36. Succow, M.; Joosten, H. Landschaftsökologische Moorkunde, 2nd ed.; Schweizerbart Science Publishers: Stuttgart, Germany, 2001.

37. IPCC. IPCC Guidelines for National Greenhouse Gas Inventories: Agriculture, Forestry and Other Land Use, 4th ed.; Institute for Global Environmental Strategies: Hayama, Japan, 2006.

38. Joosten, H.; Clarke, D. Wise Use of Mires and Peatlands: Background and Principles Including a Framework for Decision-Making; International Peat Society and International Mire Conservation Group: Greifswald, Germany, 2002.

39. Koppisch, D. Prozesse auf Moorstandorten (topische Betrachtung): Torfbildung. In Landschaftsökologische Moorkunde; Succow, M., Joosten, H., Eds.; Schweizerbart Science Publishers: Stuttgart, Germany, 2001; pp. 8-17.

40. Juranski, G.; Günther, A.; Huth, V.; Couwenberg, J.; Glatzel, S. Treibhausgasemissionen. In Paludikultur —Bewirtschaftung nasser Moore; Wichtmann, W., Schröder, C., Joosten, H., Eds.; Schweizerbart: Stuttgart, Germany, 2016; pp. 79-94.

41. Timmerman, T.; Joosten, H.; Succow, M. Restaurierung von Mooren. In Renaturierung von Ökosystemen in Mitteleuropa; Zerbe, S., Wiegleb, G., Eds.; Spektrum Akademischer Verlag: Heidelberg, Germany, 2009; pp. 55-93.

42. Gerken, B. Moore und Sümpfe: Bedrohte Reste der Urlandschaft; Rombach: Freiburg im Breisgau, Germany, 1983.

43. Dierßen, K.; Dierßen, B. Moore: 16 Tabellen; Ökologie Botanik; Ulmer: Stuttgart (Hohenheim), Germany, 2008.

44. Parish, S.; Sirin, A.; Charmann, D.J.; Joosten, H.; Minayeva, T.; Silvius, M.; Stringer, L. Assement on Peatlands, Bioderversity and Climate Change, 2nd ed.; Main Report; Wetlands International: Wageningen, The Netherlands, 2008.

45. Joosten, H.; Tanneberger, F.; Moen, A. Mires and peatlands of Europe: Status, distribution and conservation; Schweizerbart Science Publishers: Stuttgart, Germany, 2017.

46. Frolking, S.; Talbot, J.; Jones, M.C.; Treat, C.C.; Kauffman, J.B.; Tuittila, E.-S.; Roulet, N. Peatlands in the Earth's 21st century climate system. Environ. Rev. 2011, 19, 371-396. [CrossRef]

47. Schwill, S. Wirkung von Wiedervernässung auf degradierten Niedermoorstandorten: Eine Literaturecherche. In Landesamt Mecklenburg Vorpommern (Hrsg.). Stoffausträge aus wiedervernässten Niedermooren; Schriftenreihe des Landesamts für Umwelt, Naturschutz und Geologie; Landesamt für Umwelt, Naturschutz und Geologie: Güstrow, Germany, 2003; Volume 2, pp. 10-27.

48. Yu, Z.; Beilman, D.W.; Frolking, S.; MacDonald, G.M.; Roulet, N.T.; Camill, P.; Charmann, D.J. Peatlands and their role in the global carbon cycle. Eos 2011, 92, 97-108. [CrossRef]

49. Couwenberg, J.; Thiele, A.; Tanneberger, F.; Augustin, J.; Bärisch, S.; Dubovik, D.; Liashchynskaya, N.; Michaelis, D.; Minke, M.; Skuratovich, A.; et al. Assessing greenhouse gas emissions from peatlands using vegetation as a proxy. Hydrobiologia 2011, 674, 67-89. [CrossRef]

50. Couwenberg, J.; Augustin, J.; Michaelis, D.; Wichtmann, W.; Joosten, H. Entwicklung von Grundsätzen für eine Bewertung von Niedermooren hinsichtlich ihrer Klimarelevanz: Endbericht; Ministerium für Landwirtschaft, Umwelt und Verbraucherschutz Mecklenburg-Vorpommern, Institut für dauerhafte umweltgerechte Entwicklung von Naturräumen der Erde e.V.; Institut für Botanik und Landschaftsökologie Ernst Moritz Arndt Universität Greifswald: Greifswald, Germany, 2008. 
51. Köbbing, J.F.; Groth, M.; Oheimb, G. Klimaschutz durch Moorrenaturierung: Ansätze zur ökonomischen Bewertung; Ibidem-Verlag: Stuttgart, Germany, 2012.

52. Tanneberger, F.; Wichtmann, W. Carbon Credits from peatland rewetting: Climate—biodiversity—land use. Science, policy, implementation and recommendations of a pilot project in Belarus; Schweizerbart: Stuttgart, Germany, 2011.

53. Couwenberg, J. Methane emissions from peat soils: Facts, MRV-ability, emission factors; Wetlands International: Bonn, Germany, 2009.

54. Lai, D.Y.F. Methane dynamics in northern peatlands: A review. Pedosphere 2009, 19, 409-421. [CrossRef]

55. Wahlen, C. Biogeochemistry of methane exchange between natural wetlands and the atmosphere. Environ. Eng. Sci. 2005, 22, 73-92. [CrossRef]

56. Frolking, S.; Roulet, N.T. Holocene radiative forcing impact of northern peatland carbon accumulation and methane emissions. Glob. Chang. Biol. 2007, 13, 1079-1088. [CrossRef]

57. Petrescu, A.M.R.; Lohila, A.; Tuovinen, J.-P.; Baldocchi, D.D.; Desai, A.R.; Roulet, N.T.; Vesala, T.; Dolman, A.J.; Oechel, W.C.; Marcolla, B.; et al. The uncertain climate footprint of wetlands under human pressure. Proc. Natl. Acad. Sci. USA 2015, 112, 4594-4599. [CrossRef]

58. IPCC. Climate Change and Land. An IPCC Special Report on climate change, desertification, land degradation, sustainable land management, food security, and greenhouse gas fluxes in terrestrial ecosystems. Summary for Policymakers. Approved Draft; IPCC: Geneva, Switzerland, 2019.

59. Couwenberg, J.; Augustin, J.; Joosten, H. Emission reductions from rewetting of peatlands: towards a field guide for the assessment of greenhouse gas emissions from Central European peatlands; Duene and Greifswald University: Greifswald, Germany, 2008.

60. Augustin, J.; Couwenberg, J.; Minke, M. Peatlands and greenhouse gases. In Carbon credits from peatland rewetting; Tanneberger, F., Wichtmann, W., Eds.; Schweizerbart: Stuttgart, Germany, 2011; pp. 13-42.

61. Umweltbundesamt, Nationaler Inventarbericht. Berichterstattung unter der Klimarahmenkonvention der Vereinten Nationen und dem Kyoto-Protokoll 2017: Nationaler Inventarbericht zum deutschen Treibhausgasinventar 1990-2015; Umweltbundesamt: Dessau-Roßlau, Germany, 2017.

62. Gaudig, G.; Oehmke, C.; Abel, S.; Schröder, C. Moornutzung neu gedacht: Paludikultur bringt zahlreiche Vorteile. ANLiegen Nat. 2014, 36, 67-74.

63. Höper, H. Freisetzung von Treibhausgasen aus deutschen Mooren. Telma 2007, 4, 85-116.

64. IPCC. 2013 Supplement to the 2006 IPCC Guidelines for National Greenhouse Gas Inventories: Wetlands: Methodological Guidance on Lands with Wet and Drained Soils, and Constructed Wetlands for Wastewater Treatment; Intergovernmental Panel on Climate Change: Geneva, Switzerland, 2014.

65. Drösler, M.; Adelmann, W.; Augustin, J.; Bergmann, L.; Beyer, C.; Chojnicki, B.; Förster, C.; Freibauer, A.; Giebels, M.; Görlitz, S.; et al. Klimaschutz durch Moorschutz: Schlussbericht des BMBF-Projektes: Klimaschutz-Moornutzungsstrategien 2006-2010; Thünen-Institut: Braunschweig, Germany, 2013.

66. Petersen, S.O.; Hoffmann, C.C.; Schäfer, C.-M.; Blicher-Mathiesen, G.; Elsgaard, L.; Kristensen, K.; Larsen, S.E.; Torp, S.B.; Greve, M.H. Annual emissions of $\mathrm{CH}_{4}$ and $\mathrm{N}_{2} \mathrm{O}$, and ecosystem respiration, from eight organic soils in western Denmark managed by agriculture. Biogeosciences 2012, 9, 403-422. [CrossRef]

67. Augustin, J.; Merbach, W.; Steffens, L.; Snelinski, B. Nitrous oxide fluxes of disturbed minerotrophic peatlands. Agribiol. Res. 1998, 51, 47-57.

68. Eickenscheidt, T.; Heinichen, J.; Drösler, M. The greenhouse gas balance of a drained fen peatland is mainly controlled by land-use rather than soil organic carbon content. Biogeosciences 2015, 12, 5161-5184. [CrossRef]

69. Jensen, R.; Couwenberg, J.; Trepel, M. Bilanzierung der Klimawirkung von Moorböden in Schleswig-Holstein. Telma 2010, 40, 215-228.

70. Regina, K.; Nykänen, H.; Silvola, J.; Martikainen, P.J. Fluxes of nitrous oxide from boreal peatlands as affected by peatland type, water table level and nitrification capacity. Biogeocemistry 1996, 25, 401-418. [CrossRef]

71. Drösler, M.; Augustin, J.; Bergmann, L.; Förster, C.; Fuchs, D.; Hermann, J.-M.; Kantelhardt, J.; Kapfer, A.; Krüger, G.-M.; Schaller, L.; et al. Beitrag ausgewählter Schutzgebiete zum Klimaschutz und dessen monetäre Bewertung: Abschlussbericht des gleichnamigen F+E-Vorhabens (FKZ 3509 85 0500); BfN-Skripten; BfN Bundesamt für Naturschutz: Bonn, Germany, 2012.

72. Hahn-Schöfl, M.; Zak, D.; Minke, M.; Gelbrecht, J.; Augustin, J.; Freibauer, A. Organic sediment formed during inundation of a degraded fen grassland emits large fluxes of $\mathrm{CH}_{4}$ and $\mathrm{CO}_{2}$. Biogeosciences 2011, 8, 1539-1550. [CrossRef] 
73. Stubenrauch, J.; Garske, B.; Ekardt, F. Sustainable land use, soil protection and phosphorus management from a cross-national perspective. Sustainability 2018, 10, 1988. [CrossRef]

74. Zak, D.; Meyer, N.; Cabezas, A.; Gelbrecht, J.; Mauerberger, R.; Tiemeyer, B.; Wagner, C.; McInnes, R. Topsoil removal to minimize internal eutrophication in rewetted peatlands and to protect downstream systems against phosphorus pollution: A case study from NE Germany. Ecol. Eng. 2017, 103, 488-496. [CrossRef]

75. Abdalla, M.; Hastings, A.; Bell, M.J.; Smith, J.U.; Richards, M.; Nilsson, M.B.; Peichl, M.; Löfvenius, M.O.; Lund, M.; Helfter, C.; et al. Simulation of $\mathrm{CO}_{2}$ and Attribution Analysis at Six European Peatland Sites Using the ECOSSE Model. Water Air Soil Pollut. 2014, 225, 161-175. [CrossRef]

76. Koszinski, S.; Miller, B.A.; Hierold, W.; Haelbich, H.; Sommer, M. Spatial modeling of organic carbon in degraded peatland soils of northeast Germany. Soil Sci. Soc. Am. J. 2015, 79, 1496. [CrossRef]

77. Huth, V.; Hoffman, M.; Bereswill, S.; Popova, Y.; Augustin, J. The climate warming effect of a fen peat meadow with fluctuating water table is reduced by young alder trees. Mires Peat 2018, 1-8. [CrossRef]

78. Pohl, M.; Hoffmann, M.; Hagemann, U.; Giebels, M.; Albiac Borraz, E.; Sommer, M.; Augustin, J. Dynamic $\mathrm{C}$ and N Stocks-Key factors controlling the $\mathrm{C}$ gas exchange of maize in a heterogenous peatland. Biogeosci. Discuss. 2014, 11, 16135-16176. [CrossRef]

79. Zeitz, J. Aktuelle Forschungs- und Umsetzungsprojekte in Deutschland: Notwendiges Wissen über Moorböden für die Bewertung von nachhaltiger Nutzung und/oder Renaturierung. Presented at the Moore im Kontext der Ramsar-Konvention—Schutz und nachhaltige Nutzung, Bonn, Germany, 23 May 2018.

80. Wilson, D.; Alm, J.; Laine, J.; Byrne, K.A.; Farrell, E.P.; Tuittila, E.-S. Rewetting of Cutaway Peatlands: Are We Re-Creating Hot Spots of Methane Emissions? Restor. Ecol. 2009, 17, 796-806. [CrossRef]

81. Strack, M.; Zuback, Y.C.A. Annual carbon balance of a peatland $10 \mathrm{yr}$ following restoration. Biogeosciences 2013, 10, 2885-2896. [CrossRef]

82. Wilson, D.; Farrell, C.A.; Fallon, D.; Moser, G.; Müller, C.; Renou-Wilson, F. Multiyear greenhouse gas balances at a rewetted temperate peatland. Glob. Chang. Biol. 2016, 22, 4080-4095. [CrossRef] [PubMed]

83. Carter, M.S.; Larsen, K.S.; Emmett, B.; Estiarte, M.; Field, C.; Leith, I.D.; Lund, M.; Meijide, A.; Mills, R.T.E.; Niinemets, Ü.; et al. Synthesizing greenhouse gas fluxes across nine European peatlands and shrublands-Responses to climatic and environmental changes. Biogeosciences 2012, 9, 3739-3755. [CrossRef]

84. Tiemeyer, B.; Bechtold, M.; Belting, S. Moorschutz in Deutschland: Optimierung des Moormanagements in Hinblick aufden Schutz der Biodiversität und der Ökosystemleistungen; Bewertungsinstrumente und Erhebung von Indikatoren; Bundesamt für Naturschutz; BfN-Skripten: Bonn, Germany, 2017.

85. Bechtold, M.; Schlaffer, S.; Tiemeyer, B.; de Lannoy, G. Inferring water table depth dynamics from ENVISAT-ASAR C-Band Backscatter over a Range of Peatlands from Deeply-Drained to Natural Conditions. Remote Sens. 2018, 10, 536. [CrossRef]

86. Tiemeyer, B.; Freibauer, A.; Drösler, M.; Albiac-Borraz, J.; Augustin, J.; Bechtold, M.; Beetz, S.; Benrieder, M.; Beyer, C.; Eberl, J.; et al. Klimarelevanz von Mooren und Anmooren in Deutschland: Ergebnisse aus dem Verbundprojekt, "Organische Böden in der Emissionsberichterstattung"; Thünen Working Paper, No. 15; Thünen-Institut: Braunschweig, Germany, 2013.

87. Koska, I.; Succow, M.; Clausnitzer, U. Vegetation als Komponente landschaftsökologischer Naturraumkennzeichnung. In Landschaftsökologische Moorkunde; Succow, M., Joosten, H., Eds.; Schweizerbart Science Publishers: Stuttgart, Germany, 2001; pp. 112-127.

88. Gray, A.; Levy, P.E.; Cooper, M.D.A.; Jones, T.; Gaiawyn, J.; Leeson, S.R.; Ward, S.E.; Dinsmore, K.J.; Drewer, J.; Sheppard, L.J.; et al. Methane indicator values for peatlands: A comparison of species and functional groups. Glob. Chang. Biol. 2013, 19, 1141-1150. [CrossRef]

89. Comas, X.; Terry, N.; Slater, L.; Warren, M.; Kolka, R.; Kristiyono, A.; Sudiana, N.; Nurjaman, D.; Darusman, T. Imaging tropical peatlands in Indonesia using ground-penetrating radar (GPR) and electrical resistivity imaging (ERI): Implications for carbon stock estimates and peat soil characterization. Biogeosciences 2015, 12, 2995-3007. [CrossRef]

90. Gumbricht, T.; Roman-Cuesta, R.M.; Verchot, L.; Herold, M.; Wittmann, F.; Householder, E.; Herold, N.; Murdiyarso, D. An expert system model for mapping tropical wetlands and peatlands reveals South America as the largest contributor. Glob. Chang. Biol. 2017, 23, 3581-3599. [CrossRef]

91. Freibauer, A.; Röder, N.; Tiemeyer, B. Ansätze für die Definition für Gebietskulissen für den GLÖZ-Standard "Schutz von Feuchtgebieten und kohlenstoffreichen Böden einschließlich eines Erstumbruchverbots": Arbeitsberichte aus dem vTI-Institut für agrarrelevante Klimaforschung; Thünen-Institut: Braunschweig, Germany, 2012. 
92. Tanneberger, F.; Tegetmeyer, C.; Busse, S.; Barthelmes, A.; Schumka, S.; Moles Marine, A.; Steiner, G.M.; Essl, F.; Etzold, J.; Mendes, C.; et al. The peatland map of Europe. Mires Peat 2017, 19, 1-17.

93. Dargie, G.C.; Lewis, S.L.; Lawson, I.T.; Mitchard, E.T.A.; Page, S.E.; Bocko, Y.E.; Ifo, S.A. Age, extent and carbon storage of the central Congo Basin peatland complex. Nature 2017, 542, 86-90. [CrossRef] [PubMed]

94. LABO Bund/Länder-Arbeitsgemeinschaft Bodenschutz. Bedeutung und Schutz von Moorböden-Hintergrundpapier; Ministerium für Energiewende, Landwirtschaft, Umwelt und ländliche Räume des Landes Schleswig-Holstein: Kiel, Germany, 2017.

95. Osterburg, B.; Tiemeyer, B.; Röder, N. Hintergrundpapier zum Moorbodenschutz und zur torfschonenden und -erhaltenden Moorbodennutzung als Beitrag zum Klimaschutz; Thünen-Institut: Braunschweig, Germany, 2018.

96. Garske, B.; Stubenrauch, J.; Ekardt, F. Sustainable phosphorus management in European agricultural and environmental law. RECIEL 2020, 1-11. [CrossRef]

97. United Nations. Convention on Wetlands of International Importance especially as Waterfowl Habitat (Ramsar Convention); United Nations: Ramsar, Iran, 1971.

98. Bundesministerium für Umwelt, Naturschutz und nukleare Sicherheit (BMU). Handbuch der Ramsar-Konvention. Ein Leitfaden über Feuchtgebiete von internationaler Bedeutung, 4th ed.; BMU Hausdruckerei: Berlin, Germany, 2010.

99. Steiner, G.M. Moorschutz im Rahmen der Ramsar-Konvention. Presented at Moore im Kontext der Ramsar-Konvention-Schutz und Nachhaltige Nutzung, Bonn, Germany, 23 May 2018.

100. Council of the European Union. Council Directive 92/43/EEC of 21 May 1992 on the conservation of natural habitats and of wild fauna and flora, OJ L 206/7, 22.7.1992; Council of the European Union: Brussels, Belgium, 1992.

101. Peters, J.; von Unger, M. Peatlands in the EU regulatory Environment: Survey with case studies on Poland and Estonia; BfN-Skripten; Bundesamt für Naturschutz: Bonn, Germany, 2017.

102. Härtel, I. Düngung im Agrar- und Umweltrecht: EG-Recht, deutsches, niederländisches und flämisches Recht; Schriften zum Umweltrecht; Duncker \& Humblot: Berlin, Germany, 2002.

103. Douhaire, C. Rechtsfragen der Düngung: Eine Steuerungs-und Rechtswissenschaftliche Analyse vor dem Hintergrund unions- und völkerrechtlicher Verpflichtungen und politischer Zielsetzungen zum Umwelt- und Ressourcenschutz; Schriften zum Umweltrecht; Duncker \& Humblot: Berlin, Germany, 2019.

104. Federal Law Gazette, I. Federal Nature Conservation Act (Gesetz über Naturschutz und Landschaftspflege, BNatSchG); Federal Law Gazette I: Berlin, Germany, 2009; p. 2542.

105. Federal Law Gazette, I. Federal Soil Conservation Act (Gesetz zum Schutz vor schädlichen Bodenveränderungen und zur Sanierung von Altlasten, BBodSchG); Federal Law Gazette I: Berlin, Germany, 1998; p. 502.

106. Umweltbundesamt. Rechtliche und andere Instrumente für vermehrten Umweltschutz in der Landwirtschaft; Umweltbundesamt: Dessau-Roßlau, Germany, 2014.

107. Möckel, S. Landwirtschaft und naturschutzrechtliche Eingriffsgenehmigung. Anwendungsbereich und Verfassungsmäßigkeit der Regelvermutung sowie Erforderlichkeit pauschaler Kompensationspflichten. Nat. Recht 2012, 34, 225-232.

108. Möckel, S. Novellierungsbedarf beim BNatSchG aus ökologischer und europarechtlicher Sicht. Zeitschrift für Umweltrecht 2017, 28, 195-205.

109. Federal Law Gazette, I. Water Resources Act (Wasserhaushaltsgesetz, WHG); Federal Law Gazette I: Berlin, Germany, 2009; p. 2585.

110. Möckel, S.; Köck, W.; Rutz, C.; Schramek, J. Rechtliche und andere Instrumente für vermehrten Umweltschutz in der Landwirtschaft; Umweltbundesamt: Dessau-Roßlau, Germany, 2013; p. 118.

111. Garske, B.; Douhaire, C.; Ekardt, F. Ordnungsrechtliche Instrumente der Phosphor-Governance. Nat. Recht 2018, 40, 73-81.

112. Ratamäki, O.; Jokinen, P.; Albrecht, E.; Belinskij, A. Framing the peat: The political ecology of Finnish mire policies and law. Mires Peat 2019, 24, 1-12. [CrossRef]

113. Garske, B.; Hoffmann, K. Die Gemeinsame Agrarpolitik nach der Reform 2013: Endlich nachhaltig? In Beiträge zum Europa- und Völkerrecht; Institut für Wirtschaftsrecht, Forschungsstelle für Transnationales Wirtschaftsrecht, Juristische und Wirtschaftswissenschaftliche Fakultät, Martin-Luther-Universität Halle-Wittenberg: Halle, Germany, 2016. 
114. European Parliament; Council of the European Union. Regulation (EU) No 1306/2013 of the European Parliament and of the Council of 17 December 2013 on the financing, management and monitoring of the common agricultural policy and repealing Council Regulations (EEC) No 352/78, (EC) No 165/94, (EC) No 2799/98, (EC) No 814/2000, (EC) No 1290/2005 and (EC) No 485/2008, OJ L 347/549, 20.12.2013; European Parliament; Council of the European Union: Brussels, Belgium, 2013.

115. European Parliament; Council of the European Union. Regulation (EU) No 1307/2013 of the European Parliament and of the Council of 17 December 2013 establishing rules for direct payments to farmers under support schemes within the framework of the common agricultural policy and repealing Council Regulation (EC) No 637/2008 and Council Regulation (EC) No 73/2009, OJ L 347/608, 20.12.2013; European Parliament; Council of the European Union: Brussels, Belgium, 2013.

116. Deutscher Bundestag. Stellungnahme Arbeitsgemeinschaft Bäuerliche Landwirtschaft e.V. (AbL) Für Die 8. Sitzung des Ausschusses für Ernährung und Landwirtschaft uur öffentlichen Anhörung zum Gesetzentwurf der Bundesregierung "Entwurf eines Gesetzes zur Durchführung der Direktzahlungen an Inhaber landwirtschaftlicher Betriebe im Rahmen von Stützungsregelungen der Gemeinsamen Agrarpolitik (Direktzahlungen-Durchführungsgesetz-DirektZahlDurchfG)" Ausschussdrucksache 18(10)052-G; Deutscher Bundestag: Berlin, Germany, 2014.

117. EU Commission. Proposal for a regulation of the European Parliament and of the Council establishing rules on support for strategic plans to be drawn up by Member States under the Common agricultural policy (CAP Strategic Plans) and financed by the European Agricultural Guarantee Fund (EAGF) and by the European Agricultural Fund for Rural Development (EAFRD) and repealing Regulation (EU) No 1305/2013 of the European Parliament and of the Council and Regulation (EU) No 1307/2013 of the European Parliament and of the Council, COM(2018) 392 Final, 1 June 2018; European Commission: Brussels, Belgium, 2018.

118. Pabst, H.; Ahtermann, B.; Langendorf, U.; Horlitz, T.; Schramek, J. Kurzfassungen der Agrarumwelt- und Naturschutzprogramme; BfN, Bundesamt für Naturschutz: Bonn, Germany, 2018.

119. Naturschutzbund Deutschland e.V. (NABU). Leitfaden zur Naturschutzfinanzierung in der EU-Förderperiode 2014-2020, 2nd ed.; Naturschutzbund Deutschland (NABU) e.V.: Berlin, Germany, 2016.

120. Jasper, U. Eine Reform mit großen Möglichkeiten. EU-Agrarpolitik kann auf nationaler Ebene erheblich gerechter und auch grüner werden. In Der kritische Agrarbericht 2014; AgrarBünbnise, V., Ed.; ABL Verlag: Berlin, Germany, 2014.

121. Bund-Länder-Arbeitsgemeinschaft Naturschutz, Landschaftspflege und Erholung. Potentiale und Ziele zum Moor- und Klimaschutz; Bund-Länder-Arbeitsgemeinschaft Naturschutz, Lanschaftspflege und Erholung: Saarbrücken, Germany, 2012.

122. Salomaa, A.; Paloniemi, R.; Ekross, A. The case of conflicting Finnish peatland management-Skewed representation of nature, participation and policy instruments. J. Environ. Manag. 2018, 233, 694-702. [CrossRef]

123. Albrecht, E.; Ratamäki, O. Effective arguments for ecosystem services in biodiversity conservation-A case study on Finnish peatland conservation. Ecosyst. Serv. 2016, 22, 41-50. [CrossRef]

124. Van Hecken, G.; Bastiaensen, J. Payments for ecosystem services in Nicaragua: Do market-based approaches work? Dev. Chang. 2010, 41, 421-444. [CrossRef]

125. European Parliament; Council of the European Union. Directive 2009/28/EC of the European Parliament and of the Council of 23 April 2009 on the Promotion of the Use of Energy from Renewable Sources and Amending and Subsequently Eepealing Directives 2001/77/EC and 2003/30/EC (Renewable Energy Directive), OJ L 140/16, 5.6.2009; European Parliament; Council of the European Union: Brussels, Belgium, 2009.

126. European Parliament; Council of the European Union. Directive 2003/30/EC of the European Parliament and of the Council of 8 May 2003 on the Promotion of the Use of Biofuels or Other Renewable Fuels for Transport (Biofuel Directive), OJ L 123/42, 17.5.2003; European Parliament; Council of the European Union: Brussels, Belgium, 2003.

127. Schulz, C.; Martín Brañas, M.; Nuñez Pérez, C.; Del Aguila Villacorta, M.; Laurie, N.; Lawson, I.T.; Roucoux, K.H. Uses, cultural significance, and management of peatlands in the Peruvian Amazon: Implications for conservation. Biol. Conserv. 2019, 235, 189-198. [CrossRef]

128. Dohong, A.; Aziz, A.A.; Dargusch, P. A review of the drivers of tropical peatland degradation in South-East Asia. Land Use Policy 2017, 96, 349-360. [CrossRef]

129. Uda, S.K.; Hein, L.; Suarga, E. Towards sustainable management of Indonesian tropical peatlands. Wetl. Ecol. Manag. 2017, 25, 683-701. [CrossRef] 
130. Bastos Lima, M.G.; Gupta, J. The policy context of biofuels: A case of non-governance at the global level? Glob. Environ. Politics 2013, 13, 46-64. [CrossRef]

131. Lindsay, R.; Ifo, A.; Cole, L.; Montanarella, L.; Nuutinen, M. Peatlands-The challenge of mapping the world's stores of carbon and water. Unasylva 2019, 70, 46-57.

132. United Nations. Kyoto Protocol (KP); United Nations: Kyoto, Japan, 1997.

133. Wissenschaftlicher Beirat Agrarpolitik, Ernährung und gesundheitlicher Verbraucherschutz und Wissenschaftlicher Beirat Waldpolitik beim Bundesministerium für Ernährung und Landwirtschaft (BMEL). Klimaschutz in der Land- und Forstwirtschaft sowie den nachgelagerten Bereichen Ernährung und Holzverwendung; BMEL: Berlin, Germany, 2016.

134. European Commission: 2030 Climate \& Energy Framework. Available online: https://ec.europa.eu/clima/ policies/strategies/2030 (accessed on 30 August 2019).

135. European Commission: 2050 Long-Term Strategy. Available online: https:/ec.europa.eu/clima/policies/ strategies/2050_en (accessed on 30 August 2019).

136. European Parliament; Council of the European Union. Regulation (EU) 2018/842 of the European Parliament and of the Council of 30 May 2018 on Binding Annual Greenhouse Gas Emission Reductions by Member States from 2021 to 2030 Contributing to Climate Action to Meet Commitments under the Paris Agreement and Amending Regulation (EU) No 525/2013 (Burden Sharing Regulation), OJ L 156/26, 19.6.2018; European Parliament; Council of the European Union: Brussels, Belgium, 2018.

137. European Parliament; Council of the European Union. Regulation (EU) 2018/841 of the European Parliament and of the Council of 30 May 2018 on the Inclusion of Greenhouse Gas Emissions and Removals from Land Use, Land Use Change and Forestry in the 2030 Climate and Energy Framework, and Amending Regulation (EU) No 525/2013 and Decision No 529/2013/EU (LULUCF Regulation), OJ L 156/1, 19.6.2018; European Parliament; Council of the European Union: Brussels, Belgium, 2018.

138. Paul, S.; Schellenberger, A. Organische Böden, Klima und der Kohlenstoffmarkt. Bull. Bodenkd. Ges. Schweiz 2015, 36, 57-69.

139. Joosten, H.; Brust, K.; Couwenberg, J.; Gerner, A.; Bettina, H.; Permien, T.; Schäfer, A.; Tanneberger, F.; Michael, T.; Wahren, A. MoorFutures: Integration von weiteren Ökosystemdienstleistungen einschließlich Biodiversität in Kohlenstoffzertifikate—Standard, Methodologie und Übertragbarkeit in andere Regionen; BfN-Skripten; Bundesamt für Naturschutz: Bonn, Germany, 2015.

140. Chromik, P. Carbon Finance: $\mathrm{CO}_{2}$-Emissionsrechte als Anlageklasse; Diplomica Verlag: Hamburg, Germany, 2009.

141. Kind, C.; Duwe, S.; Tänzer, D.; Reuster, L.; Kleemann, M.; Krebs, J.-M. Analyse des deutschen Marktes zur freiwilligen Kompensation von Treibhausgasemissionen; Umweltbundesamt: Dessau-Roßlau, Germany, 2010.

142. Ekardt, F.; Hennig, B. Ökonomische Instrumente und Bewertungen der Biodiversität: Lehren für den Naturschutz aus dem Klimaschutz; Metropolis-Verlag: Marburg, Germany, 2015.

143. Weishaupt, A. Nachhaltigkeits-Governance tierischer Nahrungsmittel in der EU; Metropolis-Verlag: Marburg, Germany, 2019.

144. Weishaupt, A.; Ekardt, F.; Garske, B.; Stubenrauch, J.; Wieding, J. Land use, livestock, quantity governance, and economic instruments-Sustainability beyond big livestock herds and fossil fuels. Sustainability 2020, 12, 2053. [CrossRef]

145. Renou-Wilson, F.; Moser, G.; Fallon, D.; Farrell, C.A.; Müller, C.; Wilson, D. Rewetting degraded peatlands for climate and biodiversity benefits: Results from two raised bogs. Ecol. Eng. 2019, 127, 547-560. [CrossRef]

(C) 2020 by the authors. Licensee MDPI, Basel, Switzerland. This article is an open access article distributed under the terms and conditions of the Creative Commons Attribution (CC BY) license (http://creativecommons.org/licenses/by/4.0/). 